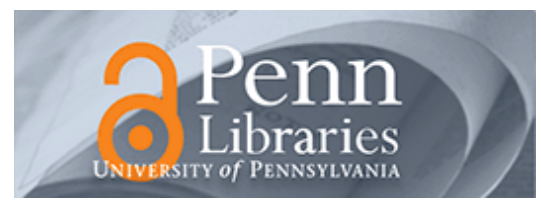

University of Pennsylvania

ScholarlyCommons

Management Papers

Wharton Faculty Research

2016

\title{
When Principals Conflict: Stakeholder Power, Executive Decision- Making, and the Manipulation of Pension Assumptions
}

Adam Cobb

University of Pennsylvania

Follow this and additional works at: https://repository.upenn.edu/mgmt_papers

Part of the Management Sciences and Quantitative Methods Commons

Recommended Citation

Cobb, A. (2016). When Principals Conflict: Stakeholder Power, Executive Decision-Making, and the Manipulation of Pension Assumptions. http://dx.doi.org/10.2139/ssrn.2763825

This paper is posted at ScholarlyCommons. https://repository.upenn.edu/mgmt_papers/182

For more information, please contact repository@pobox.upenn.edu. 


\title{
When Principals Conflict: Stakeholder Power, Executive Decision-Making, and the Manipulation of Pension Assumptions
}

\begin{abstract}
Whereas the dominant theoretical perspective in corporate governance research attends to the conflicting interests between shareholders and executives, in practice executives must frequently adjudicate between the demands of multiple principals with conflicting interests. To investigate how executives cope with these conflicts, I examine how much firms claim they will earn on the assets in their defined benefit (DB) pension plans. In a DB arrangement, participating employees forgo wages in the present in order to receive post-retirement income and they rely on executives to properly fund and manage plan assets for future payout. Executives, however, can act opportunistically by increasing the amount they expect the firm to earn on plan assets, effectively lowering their pension expenses and boosting the firm's earnings. Whether executives do so, I argue, is determined in part by the power and interests of employees and shareholders as well as the decision-making schemas of the CEO. Through a detailed analysis, I show that equity ownership by bank trusts and public pension funds and the presence of a CEO with a background in finance are associated with higher expected rates, while higher rates of firm unionization are associated with lower expected rates of return on such assets.
\end{abstract}

\section{Keywords}

corporate governance, earnings management, human resource practices, ownership, power, retirement plans, shareholder value

\section{Disciplines}

Management Sciences and Quantitative Methods 


\title{
WHEN PRINCIPALS CONFLICT: STAKEHOLDER POWER, EXECUTIVE DECISION-MAKING, AND THE MANIPULATION OF PENSION ASSUMPTIONS ${ }^{1}$
}

\author{
J. Adam Cobb \\ The Wharton School, University of Pennsylvania
}

\begin{abstract}
Whereas the dominant theoretical perspective in corporate governance research attends to the conflicting interests between shareholders and executives, in practice executives must frequently adjudicate between the demands of multiple principals with conflicting interests. To investigate how executives cope with these conflicts, I examine how much firms claim they will earn on the assets in their defined benefit (DB) pension plans. In a DB arrangement, participating employees forgo wages in the present in order to receive post-retirement income and they rely on executives to properly fund and manage plan assets for future payout. Executives, however, can act opportunistically by increasing the amount they expect the firm to earn on plan assets, effectively lowering their pension expenses and boosting the firm's earnings. Whether executives do so, I argue, is determined in part by the power and interests of employees and shareholders as well as the decision-making schemas of the CEO. Through a detailed analysis, I show that equity ownership by bank trusts and public pension funds and the presence of a CEO with a background in finance are associated with higher expected rates, while higher rates of firm unionization are associated with lower expected rates of return on such assets.
\end{abstract}

Keywords: corporate governance, earnings management, human resource practices, ownership, power, retirement plans, shareholder value

\footnotetext{
${ }^{1}$ I thank Iwan Barankay, Peter Cappelli, Jerry Davis, John Paul Ferguson, J.R. Keller, Martine Haas, Zeke Hernandez, Olenka Kascpercyk, John Paul MacDuffie, Anoop Menon, Mike Useem, and seminar participants at the Wharton Organizational Theory Workshop for thoughtful comments on earlier versions of this paper. I would also like to thank Matthew Bidwell for helpful feedback on multiple versions of this manuscript. Additionally, I thank John Byon, Constantin Gumentia, and Ben Davis for their assistance collecting data and Jiwook Jung for generiuosly providing me some data used in these analyses.
} 
Understanding the factors that influence executive decision-making is a core question of management research, as scholars have long recognized that executives often confront conflicting demands from various groups making claims on the firm’s resources (e.g., Barnard, 1938; Cyert \& March, 1963; Selznick, 1948; Weber, 1978). An important dimension of this claims-making process is that each stakeholder group has its own set of interests to be met across different time horizons, allowing the firm to make promises of varying durations to the groups based upon their preferences (Pfeffer \& Salancik, 1978: 96-100). One way firms do so is by transferring obligations between the present and future. Accomplishing this conveyance across periods requires the firm to anticipate future states based on the imperfect information available at the present. When predictions about future states prove incorrect or when past promises conflict with influential stakeholders’ expectations, keeping such promises can be challenging.

How executives manage these promises and thus adjudicate between the goals, interests, and time horizons of various stakeholders is a fundamental question of corporate governance (Davis, 2005). Researchers have predominantly studied corporate governance through the lens of agency theory, which views corporations as a nexus of contracts between principals who seek to achieve some outcome and agents, the party hired to provide the necessary assistance (Jensen \& Meckling, 1976). While enlightening, traditional agency theory focuses primarily on the contracting arrangements between shareholders and executives and thus overlooks the importance of other stakeholders, the commitments made to them by the firm, and their ability to monitor and influence executive decision-making (Aguilera, Filatotchev, Gospel, \& Jackson, 2008). In particular, in many organizational settings there exists more than one principal (Chang, 2003); however, how executives manage this complexity has not been fully examined. In particular, in a context where executives must decide between the interests of two sets of conflicting principals, what factors motivate them to favor one group over the other?

I attempt answer this question by investigating the amount firms claim they will earn on the assets set aside to finance an explicit promise made to their workers: the defined benefit (DB) 
pension. We can think of DB pensions as a form of inside debt (cf. Sundaram \& Yermack, 2007), whereby employees effectively forgo present wages in exchange for income in retirement (Kruse, 1995). To finance a DB plan, the firm must reserve enough funds to cover the future liabilities owed to workers. While there are several assumptions firms must make to do so, the expected rate of return (ERR) on pension assets is one of the most impactful on a firm's pension expenses and one that executives maintain latitude in setting. In practice, firms invest the funds they set aside to meet their future pension obligations and estimate a return on those investments. These estimates, rather than actual returns, determine the firm's pension costs. Aggressive expectations, while boosting earnings in the present, compromise the long-term health of the firm's pension fund if not matched over time by actual returns (Waring, 2012). Manipulating pension assumptions, therefore, is commonly seen as a form of earnings management (Comprix \& Muller, 2011), that is, one of a set of practices executives can use to influence financial reporting in a way that is advantageous to the firm and/or its decision-makers.

Workers, therefore, entrust executives to properly finance and manage DB plans in exchange for work done in the present. Hence, we can consider DB participants to be principals with a claim on a portion of the firm's assets. Increasing the ERR transfers funds that would have gone toward the firm's DB plan to its reported earnings, and executives have the scope to act opportunistically by doing so (Eaton, Nofsinger, \& Varma, 2014). Importantly, executives are also agents to investors (Fama, 1980)—many of whom have a shorter time horizon than workers—and the pressures executives face to appease investors may prompt executives to find ways to boost current earnings. As such, ERRs are an appealing context to assess principal-agent conflicts as executives have the discretion to allocate the firm's rewards between two principals — employees and investors—-with different interests, sources of influence, and time horizons.

Incorporating insights from socio-political theories of the firm (e.g., Cyert \& March, 1963), power-dependence perspectives (e.g., Pfeffer \& Salancik, 1978), and stakeholder theory 
(e.g., Mitchell, Agle, \& Wood, 1997), I develop a simple theoretical framework to examine how executives adjudicate between two principals. My core argument is that because complex organizations have multiple goals that often conflict, which goals executives prioritize depend, in part, upon the saliency of stakeholder interests (Agle, Mitchell, \& Sonnenfeld, 1999). Because executives have discretion in setting the ERR, I expect that their willingness to boost earnings by increasing it is guided by the power and interests of employees and shareholders as well as the decision-making schema of the firm's chief executive officer (CEO).

Through a detailed analysis of a large sample of large US employers from 1992 to 2006, I find evidence that each of these three factors affects the propensity for CEOs to change the ERR on pension assets. In so doing, I make three main advances to existing research. First, I provide a more complete depiction of the governance process, whereby employees are also principals, shareholders have diverse interests, and executives rely on their own decision-making schemas to adjudicate between the two groups. By showing that power dynamics and CEO schemas help determine how conflicts between two principals are managed, this study complements and extends literature attending to the complexity associated with managing multiple stakeholders (e.g., Arthurs, Hoskisson, Busenitz, \& Johnson, 2008; Coff, 1999; Kacperczyk, 2009).

Second, this study builds on the recent work examining how firms’ equity ownership structures and overall power dynamics affect employment-related outcomes. Unlike layoffs (Jung, 2014) or retirement plan participation (Cobb, 2015), however, with ERRs the operational and financial impetus for the change can be at least somewhat separated. This distinction is important because the tradeoff between providing additional funds to a pension plan or to firm earnings is direct and immediate, allowing for a cleaner test of how executives adjudicate between opposing stakeholders. Similarly, this study expands upon the recent work by Cobb (2015), who found that the desire to minimize the financial uncertainty that accompanies DB plans was a factor in firms decreasing the size of their plans. In this study, I show how firm ownership structure and a CEO's background help create that uncertainty and how employee 
power mitigates it. Lastly, this paper also makes an important contribution to the study of pensions as it is, to my knowledge, the first to show that employees, investors having different legal forms, and a CEO's background play a key role in how firms set their ERRs.

\section{PENSION ASSUMPTIONS AND EARNINGS MANAGEMENT}

To examine more fully how stakeholder contestation affects a firm's pension decisions, I first provide a brief overview of how firms design and account for DB plans. Firms structure their DB pensions to provide each participant a fixed, annuitized source of post-retirement income. The rate of income is determined using a formula based on the worker's length of service and wage around the time of retirement. Take this simple benefit formula:

$$
X=b * W_{f} * S
$$

where $b$ is the benefit percentage (typically between 1 and 2.5\%), $W f$ is the "final wage" based on the last year or the average of the last years of employment, and $S$ is the number of years of service in the firm. Estimating the future liability for a workforce necessitates developing predictions about the number of individuals who will retire $n$ years in the future, their expected wage rate at that time, and how many years of service they will have accumulated (Orr, 1998). The firm commits to pay the cost of these promised benefits and thus incurs a liability equal to the present value of all future payments owed to its workers. The firm funds this liability with pension assets, investing them in financial vehicles such as debt, equities, and insurance assets.

There are three key calculations required to determine the annual cost of DB plans. The first is service cost, which represents the increase in the pension obligation related to workers who have accrued another year of service. Firms also calculate interest cost, which is the interest accrued on the pension liability arising from the passage of time. The last factor is the ERR on plan assets, which is an estimate of how much the firm's pension assets will earn—a value that offsets the service and interest costs. Under Accounting Standards Codification 715, employers have discretion in choosing their pension ERRs. Accounting rules allow for the use of the expected, as opposed to the actual, rate of return in order to insulate firm earnings from year-to- 
year market swings. Over time, firms must reconcile the difference between the expected and actual returns, but this occurs over long amortization periods. ${ }^{2}$ Thus, by increasing its ERR, an employer can decrease reported pension expenses and shift its obligations to its employees further into the future. Doing so allows an executive to boost a firm’s market value, as evidence shows that earnings associated with changed pension assumptions are capitalized into the share price in a manner similar to operating earnings (Coronado \& Sharpe, 2003; Picconi, 2006).

To illustrate the impact of ERR increases on firm earnings, take the following example of IBM Inc. ${ }^{3}$ In 1997, the firm increased its ERR from 9.25 to 9.5\%, which accounted for about 1.5\% of its pretax income between 1997 and 1999. Despite poor equity market returns and declining bond yields, IBM raised the ERR again to $10 \%$ in 2000. As a result, its pretax income in 2000 and 2001 income was nearly 5\% greater than it would have been with an ERR of 9.25\%. Between 1995 and 2001, IBM’s pretax income grew at an annual compound rate of 6.7\%. Were it not for the two ERR increases, it would have grown at a rate of only 5.6\%.

To be clear, when a company like IBM states that it expects to earn a $10 \%$ return on its pension assets, it is claiming that, on average over time, the funds the firm set aside and invested to meet its liabilities will earn $10 \%$ in returns. Taking into account dividends and inflation, between 1870 and 2010, the S\&P 500’s real return averaged around 6.5\% per year. Coupling this with the fact that firms invest large portions of their pension assets in corporate and government bonds, which typically yield lower-though less volatile-returns, one might reasonably conclude than an expected return of $10 \%$ is overly optimistic. ${ }^{4}$ In fact, legendary investor Warren Buffet once critiqued the propensity of firms to use overly optimistic assumptions, stating, "I

\footnotetext{
${ }^{2}$ Deviations between actual and expected returns are entered as an off-balance-sheet, unrecognized gain or loss. The rules governing reconciliation between the actual and expected return rate are based on the corridor approach, whereby the accumulated unexpected gains or losses are compared to the beginning pension benefit obligation balance and the market value of the plan assets. Any amount greater than $10 \%$ of the larger of the two is amortized over the remaining service lives of the firm's employees (see Bergstresser, et al., 2006, for more detail).

3 This example was taken from Bergstresser, et al., (2006: 158-159).

${ }^{4}$ Prior research has found that firms hold, on average, about $26 \%$ of their assets in corporate equity and about $31 \%$ in government debt and cash, 23\% in insurance assets, and 21\% in other types of assets, such as real estate, corporate bonds, and private equity (Rauh, 2009).
} 
invite you to ask the CFO of a company having a large defined-benefit pension fund what adjustment would need to be made to the company’s earnings if its pension assumptions were lowered to 6.5 percent” (Buffett \& Loomis, 2001).

Researchers and commentators commonly view the manipulation of pension assumptions as a form of earnings management (An, Lee, \& Zhang, 2014; Revell \& Tkaczyk, 2002). Examining this type of earnings management is useful for the study of executive decisionmaking for several reasons. First, executives have substantial discretion when setting the ERR and changes to the rate reflect a conscious managerial choice. Second, unlike discretionary accruals and real activities manipulations, ERRs are directly observable and largely unrelated to other dimensions of a firm's performance that complicate analyses of these other forms of earnings management (Bergstresser et al., 2006). Finally, because ERRs are directly related to labor costs, aggressive ERR assumptions represent a transfer of assets from one stakeholder group (i.e., employees) to the firm’s earnings, which potentially benefits other stakeholders (e.g., shareholders, executives) (Comprix \& Muller, 2011). Unlike in other contexts where we see this tradeoff, such as layoffs (Jung, 2014) and employee benefit changes (Cobb, 2015), the ERR transfer is largely unrelated to the operational strategy or performance of the firm. ${ }^{5}$

\section{CORPORATE GOVERNANCE, STAKEHOLDER POWER, AND PENSION RETURN ASSUMPTIONS}

Corporate governance concerns "the structure of rights and responsibilities among the parties with a stake in the firm” (Aoki, 2001: 11). While in practice corporate governance involves balancing the interests of various stakeholders, including shareholders, management, and labor (Aguilera et al., 2008; Blair \& Roe, 1999), the primary focus of most governance research is on the methods shareholders use to discipline management. The core problem motivating most of this work is that because the actions and interests of executives often conflict

\footnotetext{
${ }^{5}$ Executives could use the extra earnings generated from an ERR increase to finance its strategic endeavors (see Bergstresser et al., 2006).
} 
with those of shareholders, shareholders rely on various internal and external control mechanisms to monitor and incentivize executives to act in accordance with their demands (Dalton, Hitt, Certo, \& Dalton, 2007; Walsh \& Seward, 1990).

While greatly informing our understanding of governance problems and potential solutions, an agency-theoretic focus may overlook some issues confronting executive decisionmakers. First, because of its focus on the bilateral contracts between shareholders and executives, agency theory typically overlooks other stakeholder claims on the firm's resources. In particular, in many organizational settings there are multiple sets of residual claimants to whom an executive is responsible (Kiser, 1999). ${ }^{6}$ Goal conflicts, therefore, do not occur simply between the agent and the principal. Rather, goal conflicts occur also in situations where an agent must "maneuver through the tangled loyalties he or she owes to many different principals and how to negotiate through their competing interests...” (Shapiro, 2005: 278). How do agents resolve these often-irreconcilable conflicts between multiple principals?

Prior research has recognized the issue of multiple principals (e.g., Bernheim \& Whinston, 1986; Hoskisson, Hitt, Johnson, \& Grossman, 2002), though most organizational research on the topic has examined conflicts between different types of shareholders (see Peng \& Sauerwald, 2013). In this line of inquiry, researchers emphasize that principal-principal conflicts are resolved by various external (e.g., laws) and internal (e.g., voting rights) governance mechanisms. In a notable exception, Adams (1996) examined the issue of multiple principals in a comparative study of the Dutch and English East India Companies, focusing primarily on how their organizational structures affected resource dependencies, thereby affecting relationships between principals and between principals and agents.

In contrast, management scholarship has long advanced the idea that executives often face a number of conflicting demands from stakeholders (e.g., Barnard, 1938; Simon, 1947). A

\footnotetext{
${ }^{6}$ Numerous scholars have asserted that viewing shareholders as the sole residual claimant is not justified in the law (e.g., Blair \& Stout, 1999; Dodd, 1932) and does not reflect organizational realities (e.g., Asher, Mahoney, \& Mahoney, 2005; Freeman, 1984).
} 
negotiation process that occurs between coalitions, which consist of groups of individuals with similar interests seeking to have their preferences met by the firm, helps determine a firm's goals and strategies (March, 1962). Coalitions often have divergent interests, and, in most cases, no single group is able to determine the goals pursued by the organization. However, what issues executives attend to and whose interests are prioritized is determined, in part, by the power and influence of the actors (Emerson, 1962; Jackall, 1988). Stakeholder theorists have also argued that, when making decisions, executives weigh the interests of various stakeholders based on their power, legitimacy, and the urgency of their demands (Mitchell et al., 1997). Therefore, the relative power of different stakeholders and changes thereto help determine the outcome of these conflicts and should be reflected in the firm's goals and strategies.

We see stakeholder conflict clearly in the context of DB pensions. While it is well established that executives are agents to shareholders (Fama, 1980) in a DB framework, employees are also principals. Pension theory argues that workers effectively forego income in the present period, trusting that the firm will manage and appropriately fund the plan and keep its promise to pay out the funds as a post-retirement annuity (Kruse, 1995). However, the firm, not the worker, owns the pension assets and liabilities (Landsman, 1986). Thus, as Shleifer and Summers (1988) argued, ex ante risk sharing between the firm and DB participants can lead to ex post opportunistic appropriation because the property rights held by pension participants are poorly defined (see also Asher et al., 2005). In sum, since workers entrust the firm with their foregone wages and because executives can use excess pension assets for their own ends (Ippolito \& James, 1992), in a DB arrangement the employee-executive relationship represents a context rife with potential principal-agent conflicts (Eaton et al., 2014).

Prior research has focused chiefly on the executives’ incentives to adjust ERRs for their own gain, finding, for example, that ERR increases occur when stock-based CEO compensation is higher (Bergstresser et al., 2006) and when the firm is likely to miss analyst estimates (An et al., 2014). Because executives are also agents to shareholders who expect that the firm will 
generate adequate returns to provide them with profit potential, executives may be inclined to manipulate the rate to benefit shareholders. In the sections below, however, I argue that employees have the ability to mitigate such manipulations and that CEOs may use their discretion to act opportunistically in order to appease investors. I also argue that the background of the CEO plays a role in determining how firms set their ERRs.

\section{Employee Power}

Though the corporate governance literature frequently neglects consideration of labor (Blair \& Roe, 1999), employees can play a key role in the governance process due to their ability to influence corporate decision-making and control resources (Aguilera \& Jackson, 2003; Coff, 1999). In a DB arrangement, firms invest workers’ foregone wages to provide them an annuitized income in retirement (Ippolito, 1987). Because compensation tends to spike upward in a DB plan as the worker nears retirement (Kotlikoff \& Wise, 1985), she has a financial incentive to remain in the firm until her benefits have fully vested. Since the firm owns the pension assets, workers' willingness to accept a DB pension necessitates that the explicit terms of the plan be matched with an implicit promise of lifetime employment (Lazear, 1986). We can therefore consider DB pensions to be both an incomplete contract that confers to workers a residual claim on a portion of the firm's assets and an implicit promise of lifetime employment in exchange for effort and loyalty (Gustman, Mitchell, \& Steinmeier, 1994).

By increasing the ERR, executives effectively push out pension costs, thereby increasing the amount of funds necessary in the future to match the obligations owed to workers. In so doing, the firm increases the probability that it will, in the future, fully renege on its pension promise by terminating or freezing its plan (Waring, 2012). Consequently, workers can be negatively affected by higher ERRs. Research has found that worker power influences key elements of the employment relationship, such as the amount of employment security and stability (Bidwell, 2013; Dencker, 2009). As such, I expect that as workers in a firm obtain (lose) power, the firm's ERRs will be lower or higher. 
Individual employees have little power to influence an organization’s goals and strategies, but when workers mobilize and act collectively, their power is greater (Coff, 1999). The primary means by which employees do so is via unionization, which provides workers an institutionalized apparatus to exert influence on firms by engaging in or threatening strikes and slowdowns and by expressing demands through collective bargaining. Evidence has shown that unions play a crucial role in how much discretion firms have in structuring their employment relationships. For example, unions have been shown to deter the use of contingent employment relationships (Gramm \& Schnell, 2001) and are associated with longer employment tenure (Bidwell, 2013) and improved benefits and wages (Freeman \& Medoff, 1984). Though DB pensions present a case where younger workers may have interests that conflict with those of older employees (Dencker, Joshi, \& Martocchio, 2009), in a union setting the interests of the average worker predominate. Because the average worker is likely to be older and have higher exit costs, when workers bargain collectively they tend to seek more security (Goldberg, 1980), which DB pensions are designed to create (Cobb, 2015).

Labor organizations have also served as important monitors of firms’ employment and corporate governance practices, and anecdotal evidence suggests that unions have been outspoken against firms’ aggressive ERR assumptions (Solomon \& Hawkins, 2005). Moreover, firms may be prone to decrease their ERRs prior to labor negotiations to make the plan appear more costly and use this a lever when seeking wage and/or benefit concessions (Benmelech, Bergman, \& Enriquez, 2012). As such, I expect that when workers have greater levels of power in a firm, its executives will use less-aggressive ERR assumptions.

Hypothesis 1: A firm's level of unionization will be negatively related to its expected rate of return on pension assets.

\section{Shareholder Power and Fiduciary Standards}

Shareholders invest in corporations primarily for economic gain, which comes in the form of dividends or by selling part of their interest in the firm for profit. Shareholders, then, 
make the decision to invest based on the belief that, in the future, the firm will (a) distribute some of its returns and/or (b) the value of the firm's shares will increase, allowing them to profit when selling shares (Velasco, 2006). Firms respond to investor pressures because of their ability to initiate and engage in various forms of activism (Filatotchev \& Toms, 2006) and because the liquidation of their shareholdings reduces the value of the company, which raises the cost of capital (David, O'Brien, Yoshikawa, \& Delios, 2010; Parrino, Sias, \& Starks, 2003). Extensive research has examined how investors influence executive decision-making in order to enhance shareholder returns (e.g., Connelly, Tihanyi, Certo, \& Hitt, 2010; Useem, 1996). A key finding from this work is that the structure of equity ownership helps shape the political dynamics within a firm and directly affects its goals and structure (Fiss \& Zajac, 2004).

There are, however, different types of shareholders with different goals, objectives, and time horizons (see Connelly, Hoskisson, Tihanyi, \& Certo, 2010). In this study, I focus on institutional investors. This is the largest class of equity owners in the United States, and a category that receives considerable scholarly interest (e.g., Hoskisson et al., 2002; Jung \& Dobbin, 2014). Notably, in the context of earnings management, some research has argued that due to their ability and willingness to monitor management, institutional investors discourage accruals management (e.g., Chung, Firth, \& Kim, 2002; Hadani, Goranova, \& Khan, 2011) and ERR increases (Eaton et al., 2014). Others have found, however, a more complex relationship between institutional shareholding and earnings management, such as when current shareholders benefit from earnings management at the expense of future shareholders (Guthrie \& Sokolowsky, 2010) or when shareholders have a shorter investment horizon (Koh, 2007).

As these studies reveal, there are many types of institutional investors-public and company pension funds, banks, insurance companies, and mutual funds, for example — that differ along a number of attributes. One point of differentiation between them is the stringency of their fiduciary responsibilities to clients. Though all institutional investors have discretion over how they invest their clients' assets and are legally considered fiduciaries, the strictness of the 
standards of prudence differs based on the investors’ legal form (David, Kochhar, \& Levitas, 1998). Prudent-man laws are designed to protect clients by allowing them to seek damages when a fiduciary fails to invest in the clients' best interest. Though institutions typically own a diverse array of stocks, court rulings stipulate that the merits of each stock in the portfolio be assessed individually to determine prudence (Badrinath, Gay, \& Kale, 1989). As a result, investors held to stricter fiduciary standards have a strong incentive to protect themselves from liability by tilting their portfolios toward firms with better current-earnings performance, which the courts often use to determine the prudence of an investment (Del Guercio, 1996).

Not surprisingly, research has shown that institutional investors with stricter fiduciary standards are more sensitive to the short-term earnings performance of the individual stocks in their portfolio (e.g., Bushee, 2001). Since the benefit of increasing the ERR is an immediate enhancement of current-year earnings, I expect that the stringency of fiduciary standards will play a key role in how executives set the ERR. While I do not necessarily expect that shareholders specifically request that a firm raise its ERR, when shareholders value near-term returns and directly or indirectly pressure firms to provide it, I expect that manipulating their pension assumptions is a tactic firms will be more apt to use.

To test the impact of fiduciary restrictions on ERRs, I split institutions into five groups based on their legal form — investment advisors (including mutual funds), insurance companies, bank trusts, public pension funds, and company pension funds — as prior research has found significant differences across these classifications for preferences for current earnings (Abarbanell, Bushee, \& Raedy, 2003). Investment advisors primarily manage individual investments through mutual funds. While the Model Prudent Investment Act of 1940 imposes a fiduciary responsibility on mutual fund managers, it makes no reference to prudent investments. Therefore these managers are held to the least-restrictive fiduciary responsibilities among institutional investors, granting them great latitude in selecting firms in which to invest (Del Guercio, 1996). Insurance companies hold equities as an investment vehicle for their premiums. 
Compared to mutual funds, insurance companies are subject to stricter fiduciary constraints; however, these restraints are still relaxed when compared to those for banks and pension funds. The three types of institutions with the most stringent fiduciary standards are bank trusts, public pension funds, and company pension funds. Bank trusts manage equities on behalf of other institutions, including pension funds and endowments, and face particularly strict fiduciary requirements that motivate them to avoid investments the courts would deem imprudent (Badrinath et al., 1989). Because current-earnings performance is the key criteria used to determine the prudence of an investment, banks should find firms with better near-term earnings performance to be safer, and thus more attractive, investments. In fact, Del Guercio (1996) found that bank trust managers invest more heavily in stocks with a better Standard \& Poor’s Earnings and Dividend Ranking — a measure often used in courts to defend a stock investment as prudent — while mutual fund managers do not. Similarly, Bushee (2001) found that equity ownership by bank trusts is associated with a preference for near-term earnings over long-run value. Therefore, firms with a higher percentage of bank ownership may feel heightened pressure to continue solid earnings performance given the risk of such investors liquidating their holdings.

Public pension funds, as retirement vehicles for public-sector workers, also face strict fiduciary responsibilities under the state and local laws governing their investment operations (Shin \& Seo, 2011). Research has found that the fear of litigation is a particularly strong motivating investment criterion for public pension managers (O'Barr \& Conley, 1992). Similarly, under the Employment Retirement Investment Security Act of 1974 (ERISA), managers of company pension funds are personally liable for losses on imprudent investments. Thus both public and company pension fund managers have a strong incentive to invest in safe, highquality stocks (Bushee, 2001; Del Guercio, 1996). In sum, based on their more stringent fiduciary standards, we should expect that as the percentage of a firm's shares owned by public or company pension funds increases, the firm will be more willing to increase its ERR to 
maintain or improve earnings. Doing so makes the firm a more attractive investment and lowers the probability that these investors will liquidate their holdings.

Nevertheless, prior research has contended that pension funds are a more patient form of capital with a longer-term investment horizon (Tihanyi, Johnson, Hoskisson, \& Hitt, 2003), and ownership by these funds is associated with firms that are more socially responsible (Johnson \& Greening, 1999). Pension funds also prefer CEO pay to be tied less closely to firm performance as such linkages might encourage unnecessary risk taking and earnings management (Shin \& Seo, 2011). It is also possible that pension fund managers hold a more conservative view toward earnings garnered from pension changes. These managers may be better informed about the impact of ERR increases and are thus more effective monitors of firms’ pension plans. The study of pension manipulations, therefore, presents a unique context to examine how pension fund ownership affects executive decision-making.

More generally, one might expect investors to discount any returns garnered through ERR increases. A number of studies have found, however, that investors do not effectively assess the impact of pension accounting on firm value. For example, Coronado and Sharpe (2003) found that earnings due to changed pension assumptions were capitalized into share prices in a manner equivalent to operating earnings (see also Picconi, 2006). In a related vein, Franzoni and Marin (2006) found that firms with underfunded pension plans are overvalued by the market, as investors do not anticipate the impact of pension liabilities on future earnings. The accounting literature surmises that the complexity of pension accounting, where much of the pertinent information is embedded in footnotes, makes it challenging for investors to effectively value plan changes (Coronado, Mitchell, Sharpe, \& Nesbitt, 2008; Picconi, 2006). It is also plausible that investors that place greater value on firms with better current earnings performance are relatively indifferent to earnings generated from pension changes versus operations.

Despite their transitory impact on reported income and the often arbitrary nature in which these assumptions are set, higher ERRs are associated with increased earnings and share prices, 
providing such shareholders with greater profit potential—at least in short-run (Coronado \& Sharpe, 2003). Based on the stringency of fiduciary standards for banks, public pension funds, and company pension funds, I expect that firms with higher levels of ownership by these institutions will be more compelled to increase their ERRs.

Hypothesis 2: A firm's level of institutional ownership by (a) bank trusts, (b) public pension funds, and (c) company pension funds will be positively related to its expected rate of return on pension assets.

Though I do not hypothesize a relationship between insurance companies and investment advisors on the one hand and ERR changes on the other, I control for these investor types in my analyses. These controls can be viewed as a benchmark to test whether fiduciary standards are a determinant of institutional investor preferences for near-term earnings (Bushee, 2001).

\section{CEO Background and Decision-Making}

Equity owners of large corporations typically delegate control over firm resources to management. While constraints on their discretion exist, by the nature of their position top executives have substantial authority to set firms' goals and strategies (Fligstein, 1991; Graffin, Boivie, \& Carpenter, 2013). Thus, while complex organizations are composed of stakeholder groups with competing interests vying for resources and attention, the arbiters of much of this conflict in modern corporations are executive decision-makers (Longo, 2000).

The literature on earnings management has focused considerable attention on CEO incentives to manage earnings, finding, for example, that CEOs are more willing to manage accruals when they receive greater levels of performance-based compensation (Zhang, Bartol, Smith, Pfarrer, \& Khanin, 2008) or in order to secure permanent employment (Chen, Luo, Tang, \& Tong, 2015). Similarly, prior research on pension-assumption manipulations has focused on CEO incentives to manipulate the ERR, finding that ERR increases occur when stock-based CEO compensation is higher (Bergstresser et al., 2006) and when the firm is likely to miss 
analyst estimates (An et al., 2014). In this study, I complement and extend this prior work by examining how the background of CEOs affects their willingness to change the ERR.

When faced with similar circumstances, different executives may make substantially different decisions based on their individual understanding of those situations. As such, firmlevel characteristics and outcomes can be linked, in part, to the experiences and schemas of senior executives (see Finkelstein, Hambrick, \& Cannella, 2009). Executive beliefs about the most effective tactics and strategies are likely to emerge from prior experience (Skinner, 1953), as prior training and experience have an enduring effect on an individual's cognition and decision-making schemas (Dearborn \& Simon, 1958; Prahalad \& Bettis, 1986). The functional background of a firm's top executive, therefore, is likely to play a role in determining how conflicts between various stakeholders are resolved and hence in setting the objectives and strategies of the firm (Fligstein, 1990; Ocasio \& Kim, 1999).

CEOs with a background in finance are of particular interest to the study of ERRs, as there are at least two explanations for why such CEOs might be more likely than others to manipulate this rate. First, training and early career experience in finance are thought to affect CEOs' commitment to the primacy of markets and the belief that shareholders are the sole stakeholder to whom the firm is beholden (Fiss \& Zajac, 2004). A shareholder primacy view may encourage a shorter investment time horizon and provide a justification for maximizing rents to equity holders by reducing rents to labor and other stakeholders (Goldstein, 2012). Because finance CEOs tend to hold such a view, they are thought to view labor as a cost to be minimized (Fligstein \& Shin, 2007), and research has found that CEOs with a background in finance are more likely to engage in downsizing (Budros, 2000; Jung, 2014). Hence, theory suggests that executives with a background in finance will hold a positive view toward minimizing a firm's long-term obligations to its workers as the demands and concerns of workers are likely to be viewed as less salient (Bundy, Shropshire, \& Buchholtz, 2013). 
Second, evidence suggests also that CEOs with a background in finance are more financially sophisticated —-more specifically, they have been found to be better able to raise external capital, less likely to hold cash, more likely to issue debt, and are thought to follow more aggressive financial policies (Custodio \& Metzger, 2014). Thus, in addition to their proclivity to put the interests of shareholders ahead of those of other stakeholders, one might expect CEOs with a background in finance to have a greater awareness and understanding of the consequences of raising a firm's ERR and to see this as a way to manage earnings without the risk of impropriety. Altogether, given their predisposition toward a market orientation and attention to financial measures of performance, as well as their greater knowledge and understanding of financial instruments, I expect that when a firm has a finance CEO, its ERR will be higher. Hypothesis 3: Compared to firms with CEOs that have other functional backgrounds, the presence of a CEO with a background in finance will be positively related to its expected rate of return on pension assets.

\section{DATA AND METHODS}

\section{Sample}

Because my central interest is examining the drivers of firms’ ERRs, I focused my analysis on large US firms that had a DB plan during the period of study. Though it is also important to understand trends in the retirement plan use of all firms, I focused on larger firms during this period because they were most likely to have DB pensions and were most subject to changes in the competitive and ideological landscape that might motivate their use of pension assumptions as a form of earnings management.

The common practice among researchers of drawing their samples from a single year when studying large firms can create survivorship bias. Because this study covers a long period that saw a great deal of turnover among the largest firms (Davis \& Stout, 1992), I wanted to capture the relevant dynamics by sampling from multiple points in time. I originally began my analysis by examining the years 1986 to 2006 - a choice motivated by the fact that new Financial 
Accounting Standards Board (FASB) guidelines were passed in 1985, making 1986 the first year in which a change in pension assumptions under the new guidelines could have occurred. The initial sample included all publicly traded firms that had a DB plan and were included on the 1986 Fortune 500 list of largest industrials, the 1995 Fortune 1000 list, or the Fortune 500 list for 2007. This selection generated an unbalanced sample of 938 firms. However, because some of the CEO data were available from only 1992 onward, the primary analyses I present here use data for 1992 to 2006 only, yielding an unbalanced sample of 728 firms. I did run, however, models without the CEO variables for the full complement of years and discuss those results below. These analyses are available upon request.

\section{Variables}

Expected rate of return. My dependent variable is the expected rate of return on pension assets. The ERR data come from two sources: Form 5500 reports and Compustat. Each year, firms offering retirement plans to their workers must submit a Form 5500 report that details information about the plan. I had a small number of instances in which the ERRs for a firm's different plans were not the same. In these instances, I used the rate of the largest plan. One of the challenges with using the Form 5500 is missing data, that is, there are a number of observations each year for which the ERR is not available. I therefore supplemented these data with data from Compustat, which has information on firm ERRs beginning in 1991. For ease of interpretation, I multiplied the ERR by 100 and presented the ERR in basis points.

Unionization. I included a measure of employee power, unionization, which is the percentage of a firm's DB participants covered by collectively bargained plans. These data come from the Form 5500 reports, which include a field indicating whether a pension plan is part of a collective bargaining agreement. Unions often stipulate that some firm decisions, particularly those directly affecting employees covered by a collective bargaining agreement, require union participation (Freeman \& Medoff, 1984). Collectively bargained plans, therefore, limit the ability of firms to modify the plan's terms unilaterally. I note here that in some cases workers in a firm 
may be represented by a union but are not participants in a collectively bargained plan. In other instances, not all workers participating in a collectively bargained plan may be part of the union, as if any part of a pension plan is covered in a collectively bargained agreement then it is considered a unionized plan. Given these potential issues, I also used the rate of unionization in the firm’s focal industry and the results are similar to those presented below.

Institutional share ownership. For each firm in each year, I took the percentage of the total number of shares outstanding for the focal firm owned by institutional investors as classified in each of the different types: Bank, Public Pension, Company Pension, Insurance Company, and Investment Advisor. ${ }^{7}$ Unlike measures of overall institutional share ownership, these measures have the advantage of assuming that institutional investors' interests, and their influence on firm strategies, vary based upon fiduciary standards. The data come from Bushee (1998) and are lagged one year.

CEO background. The functional background of CEOs was coded manually based on their prior work experience. I coded individuals who served in an accounting or finance-related position — such as chief financial officer, controller, or treasurer - as a Finance CEO. Because the ERR is typically set early in the fiscal year (Picconi, 2006), I considered the CEO of record to be the individual working at the end of quarter one of each fiscal year. In the analyses below, I compared finance CEOs with all other CEO background types. ${ }^{8}$ The information was collected from Who's Who in Finance and Industry and supplemented with information from the Dun \& Bradstreet Reference Book of Corporate Management and company proxy filings.

Control variables. A firm's ERR may relate to factors not included in the discussion of the hypotheses. To account for firm size, I included the lagged log of Total Assets. I included a

\footnotetext{
7 There are two other categories of institutional investors: foundations (including universities) and miscellaneous. Including these does not materially affect the results.

${ }^{8}$ I also coded four additional CEO background categories: (1) General Management (including operations), (2) Sales and Marketing, (3) Engineering and other technical jobs (e.g., chief information officer), and (4) Law. In analyses not presented here, I found that, in comparison to all other CEOs, those with a background in law are significantly and negatively associated with ERRs. The other CEO background types had no significant effect on ERRs and were not significantly different from one another with respect to ERRs.
} 
measure of Revenue Growth, a common control in studies of earnings management as it may be related to the ability of firms to finance their DB plans. To account for performance, I took the company’s previous-year Return on Equity (ROE). Analyses using return on assets yield similar results. Because this variable has some extreme values, I winsorized this figure at the $99^{\text {th }}$ and $1^{\text {st }}$ percentiles. The employment and financial data come from Compustat. I included a measure of Long-term Debt to Total Assets, lagged one year, as a measure of the firm's relative covenant constraints. I also winsorized this figure at the $99^{\text {th }}$ percentile as it contained some extreme values at the upper end. The employment and financial data come from Compustat.

The size of a firm's pension plan or plans may make it more willing to increase the ERR of its pension assets; therefore I also controlled for the size of the firm’s DB pension plan(s) using the log total of all of the assets the firm has in its DB plan(s) (DB Assets). I also included a measure of the Funding Status of the firms’ pension plan or plans from the previous year. Calculated as the ratio of the fair market value of the firm's pension assets to its projected benefit obligations multiplied by 100, the ratio represents whether the firm’s pension plans are adequately funded. Executives of firms with a higher funding status ratio may be inclined to raise the ERR. Pension-participation, asset, and liability data were taken from the Form 5500 filings and Compustat and the operating asset data from Compustat.

To account for the possibility that other governance mechanisms may affect the relationship between the independent variables and ERR increases, I included several control variables. First, I include a measure of Shareholder Rights, which measures the number of practices the firm adopted that grant (or restrict) shareholder rights. I used the governance index (Gompers, Ishii, \& Metrick, 2003) obtained from the Investor Responsibility Research Center (IRRC) governance database and reverse-coded it such that higher values equal greater shareholder rights. I also included a control measure for CEO Tenure, as a CEO might use different decision-making criteria as she becomes more experienced. Prior research has also shown that CEOs who are more entrenched have greater influence and may be monitored less 
rigorously than their less-tenured counterparts (Dikolli, Mayew, \& Nanda, 2014). Prior work has also found a positive relationship between option-based executive compensation and higher ERRs (Bergstresser et al., 2006). Hence, I included the ratio of stock-option pay to total pay (CEO Pay from Options) for the firm's CEO, where the option value is calculated using the Black-Scholes methodology of valuation. For robustness, I also examined the log value of options; the impact on the hypothesized covariates was immaterial. The CEO pay and tenure data come from the Compustat Executive Compensation database. Finally, because the threat of acquisition is thought to discipline management (Manne, 1965), to account for the fact that some firms face more active acquisition markets, I include a lagged count of mergers and acquisitions (Industry Mergers) at the two-digit Standard Industrial Classification (SIC) code level. These data come from the Securities Data Company (SDC) Platinum database.

CEOs have strong incentives to report earnings that match or exceed those expected by analysts, as missing an earnings target has negative consequences for the firm's stock price and CEO compensation (Skinner \& Sloan, 2002). Though Picconi (2006) found that the ERR is set at the beginning of the fiscal year typically, thus making pension assumptions an imperfect tool to manage earnings, An et al. (2014) found evidence that firms do increase the ERR to make their reported earnings meet or exceed analyst forecasts. To account for this possibility, I included two control variables. The first is a binary indicator, Missed Earnings, which is equal to 1 when the firm missed its earnings target for the year. This is calculated by subtracting the firm's reported earnings per share (EPS) from the median analyst forecast for the year.

The second indicator, Avoid Missed Earnings, is set to 1 when the firm met or exceeded its earnings forecast but would not have had it not increased its ERR. Following the procedure used by An et al. (2014), I calculated an adjusted EPS using the following formula:

$$
E P S^{\prime}=E P S-[(\triangle E R R * F V P A *(1-M T R)] / \# \text { of common shares outstanding }
$$
where EPS is the reported earnings per share, $\triangle E R R$ is the change in the firm's ERR from the previous year, FVPA is the fair value of pension assets, and MTR is the marginal tax rate. This 
yields an estimate of the firm's EPS had it not changed its ERR. I subtracted from this figure the median analyst earnings estimate to determine whether the firm would have missed its estimate had its ERR not changed. When a firm made its earnings estimate but would not have had the ERR remained unchanged, Avoid Missed Earnings, was coded 1. The ERR and pension asset data were taken from the Form 5500 and Compustat. The marginal tax rate data were taken from Blouin et al. (2010), the EPS and common share data from Compustat, and the median analyst forecast data from Thomson Reuters’ Institutional Brokers’ Estimate System (IBES) database.

Additionally, I controlled for the possible effect of the retirement practices of industry peers on a firm's retirement policy by creating the variable Industry Average ERR. This figure represents the average ERR among firms in my sample sharing the same two-digit SIC code. To account for unobserved effects that may matter for a given year, I controlled for time using year dummy codes. Descriptive statistics and correlations are presented in Table 1.

[--- Insert Table 1 about here ---]

\section{Analytic Approach}

In this study, the unit of analysis is the firm and the unit of observation is the firm year. To examine the relationship between ERRs and the covariates, I used a pooled time-series regression analysis with firm fixed effects. A fixed-effects model accounts for firms' unobserved characteristics that do not vary over time that may affect ERRs. This specification is achieved by subtracting the values of each observation from the firm mean, removing all between-firm differences, and leaving only within-firm variation to be explained by the covariates.

Specifically, I estimated the effects of the covariates on ERRs as follows:

$$
Y_{i j}=\beta_{0}+\beta_{1} X_{1 i j}+\ldots+\beta_{p} X_{p i j}+\alpha_{j}+\varepsilon_{i j}
$$

where all firm-specific effects are accommodated by $\alpha_{j}$ and within-firm effects are explained by the covariates. A fixed-effects framework strengthens the inferences about the effects the covariates have on ERRs by ruling out the possibility that firms that adopted those rates had stable unobserved preferences for their value. Furthermore, because fixed effects allow for the 
correlation between $\alpha_{j}$ and all $X_{i j}$, whereas a random effect does not, under most conditions a fixed effect is considered to be a more convincing estimation method (Wooldridge, 2006). A Hausman test indicated that the fixed-effects model was appropriate $\left(\chi^{2}=47.32, \mathrm{p}<.01\right)$. Using variance inflation factor tests, I found that multi-collinearity was not an issue.

\section{RESULTS}

The results of the fixed-effects regressions are in Table 2. Model 1 contains the results for the independent variables. In Model 2, I included only the control variables. Model 3 shows the results of the full model. Across models, several control variables are significantly related to ERRs. ROE has a modestly significant and negative impact on ERR changes across models, suggesting that when a firm's financial performance wanes its executives increase the ERR. The funding status of the plan is negatively related to ERRs at the .10 level in Model 2 but is insignificant once the full model is specified. Shareholder rights are also negatively and significantly related to ERRs, suggesting that as firms adopt mechanisms that curtail managerial discretion, their ERRs decline. CEO tenure is positively and significantly related to ERRs, suggesting that as executives gain experience and become more entrenched in their role, they are more likely to increase the ERR. The results indicate that executives are significantly more likely to increase the ERR when doing so allows the firm to avoid missing its earnings target. Finally, firms in industries with higher ERRs in the previous year are also likely to increase their ERR.

[--- Insert Table 2 about here ---]

Because employees have an interest in ensuring their pension benefits remain stable and secure, I predicted that employee power would be negatively associated with ERRs. Lending support for Hypothesis 1, the results in Models 1 and 3 show a significant, negative relationship between unionization and ERRs. I also ran analyses with a binary indicator as to whether the firm has at least one collectively bargained plan, and those results were significant and negative as well. It is important to note that for firms with at least one unionized plan, on average $45 \%$ of 
its DB participants are members of a collectively bargained plan. Therefore, the presence of a collectively bargained plan in a firm helps participants in non-unionized DB plans.

Hypotheses 2a, b, and c predicted a positive relationship between equity ownership in the previous year by bank trusts, public pension funds, and company pension funds, respectively, and ERRs. Across models, the results indicate that the percentage of ownership by banks is positively associated with ERR increases, lending credence to the argument that when a firm has a higher percentage of its shares owned by investors with stronger fiduciary standards, its executives seek to enhance current earnings performance by increasing the ERR. Hypothesis 2a is therefore supported. Supporting Hypothesis $2 \mathrm{~b}$, the results also indicate a significant and positive relationship for public pension fund ownership and ERRs. While consistent with the theory that more stringent fiduciary standards motivate investors to prefer that firms report higher near-term earnings — as such firms are deemed to be prudent investments — this finding runs counter to previous work that argues that pension funds have a longer-term investment horizon. I take up this point further in the discussion.

In contrast to the results from banks and public pension funds, in Model 1 there is a negative and significant relationship between share ownership by company pension funds and ERRs, which runs counter to Hypothesis 2c. However, once the full model is specified, the effect is insignificant. While Hypothesis 2c is not supported, these results may suggest that, despite their commensurate fiduciary responsibilities, company pension funds hold a more conservative view toward earnings garnered from ERR increases than do banks or public pension funds. In analyses from 1986 to 2006 without the CEO covariates, the effects for unionization and equity ownership by bank trusts, public pension funds, and company pension funds are substantively the same as those presented here.

Hypothesis 3 predicted that, compared to other CEOs, the presence of a CEO with a finance background will be positively related to ERRs. Confirming this hypothesis, the results support the argument that because finance CEOs have a preference to maximize short-term 
earnings and/or are more financially sophisticated, they are more willing to increase ERRs. These findings reinforce those from other studies that suggest that finance CEOs make decisions that favor shareholder welfare over that of other constituents (e.g., Budros, 2000; Jung, 2014).

\section{Supplemental Analyses}

In observational studies of this type, establishing causality between the covariates and the dependent variable can present a significant challenge, and I am aware of concerns about endogeneity affecting these results along with any inferences made about causality. I attempted to deal with these concerns empirically using three different analyses: an error-correction model, a two-stage least-squares analysis, and a triple-difference analysis.

Error-correction model. I first attempted to address endogeneity concerns using an autoregressive analysis: the single-equation error-correction model (ECM). The single-equation ECM used in the analyses is specified as follows:

$$
\Delta Y_{i, t}=\alpha_{0}+\alpha_{1, j}+\beta_{1} \Delta X_{i, t}-\beta_{2} \Delta \gamma_{, i, t-1}+\beta_{3} \Delta X_{i, t-1}+\varepsilon_{i, t}
$$

where $\Delta Y_{\mathrm{t}}$ denotes the first difference of the dependent variable $\left(Y_{\mathrm{t}}-Y_{\mathrm{t}-1}\right) ; \alpha_{0}$ denotes the grand mean; $\alpha_{1, \mathrm{j}}$ denotes firm-year deviation; $\beta_{1}$ denotes the contemporaneous coefficient, which absorbs any endogenous relationship between the explanatory covariate and the dependent variable; $\beta_{2}$ denotes the error correction rate of $Y$; and $\beta_{3}$ denotes the impact of $X_{\mathrm{t}-1}$ on $\Delta Y_{\mathrm{t}}$. I identified the relationship between the covariates and ERRs by estimating the effect of the variables on future ERRs, holding the past ERRs and concurrent changes in the covariates constant. Therefore, any concurrent endogenous association between the covariates and ERRs is accounted for in $\beta_{1}$, which is not used to identify the causal relation between the covariates and ERRs. In these models, I included dummy codes for the two-digit SIC code of the focal firm.

Though I ran analyses on the full complement of controls, because of the large number of variables in the ECM, I included only the results of the hypothesized covariates in Table 3 . The full model is available upon request. The results in Model 4 largely reinforce the fixed-effects results with two important exceptions. Though the short-run impact of public pension fund 
ownership is positive and significant, the long-run effect of public pension fund ownership is not, suggesting only a modest effect of public pension ownership on ERRs. Furthermore, consistent with the findings from Model 1, the results also indicate a negative and significant long-run effect between company pension fund ownership and ERRs. While I cannot completely rule out concerns of endogeneity because the ECM takes into account the impact of past ERRs and changes in the covariates, I am more confident that the relationships hypothesized here work in the theorized direction and are not correlational or the result of reverse causality.

[--- Insert Table 3 about here ---]

Two-stage least-squares model. To attempt to address any concern that bank, public pension fund, and company pension fund ownership shares are endogenous with the dependent variable, I used a set of two-stage least-squares (2SLS) models with fixed effects. In a traditional ordinary least-squares framework, there is a basic assumption that the error term is independent of the predictor variables. 2SLS helps correct issues that arise when this assumption is violated. In the first stage of the analysis, the endogenous regressor is regressed on the instrument variable (IV) and the covariates, which isolates the variation in the predictor that is not correlated with the error term. The fitted value from the first stage is then used in the second stage in place of the endogenous regressor, allowing us to interpret the coefficient of the endogenous regressor as “capturing a covariate-adjusted causal effect” (Bascle, 2008: 294; Wooldridge, 2006).

I used the number of Analysts covering a firm in the previous year as an IV for institutional ownership. While the number of analysts covering a firm helps predict institutional ownership (Cornett, Marcus, Saunders, \& Tehranian, 2007), I do not expect it to be influenced by firms’ pension policies. That is, I expect that analyst coverage will be correlated with share ownership by bank trusts, public pension funds, and company pension funds, but the number of analysts covering a firm should not be subject to reverse feedback from variations in a firm’s ERR. Prior research has used the number of analysts as an IV to predict the impact of institutional ownership on firm performance (Cornett et al., 2007) and opportunistic ERR 
increases (Eaton et al., 2014). One of the limitations here, however, is that I have three categories of institutional investors but must use this IV for each type. Hence, I ran separate regressions analyzing one investor type at a time with the number of stock analysts as the IV.

[--- Insert Table 4 about here ---]

The results of the 2SLS regressions appear in Models 5 through 7 in Table 4 . As the results indicate, the relationship between bank (Model 5) and public pension fund (Model 6) share ownership remains positive and significant. However, in the second stage of these models, the unionization and finance CEO variables are insignificant. Several other control variables that were previously significant—including ROE, shareholder rights, CEO tenure, and —are also insignificant in Model 6. It is possible that the lost efficiency inherent in these analyses has affected the relationships between these other covariates and the dependent variable (Bascle, 2008). If so, a more strongly identified model would likely improve these results. ${ }^{9}$ In Model 7 , the results for company pension fund ownership remain insignificant. Though the use of a single instrument across the three models is not ideal, the results do offer some confirmation of the previous findings regarding bank and public pension fund equity ownership.

Triple-differences analysis. Difference-in-difference (DD) approaches are a popular way to estimate causal effects using observational data. They are particularly useful for estimating the effects of policy interventions that do not affect all actors similarly. DD estimation compares the differences in outcomes before and after a treatment (first difference) for groups affected by the treatment to before-and-after outcomes of groups unaffected by it (second difference). In December 2002, the Securities and Exchange Commission (SEC) issued a warning that it might challenge ERRs set above 9\%. While the warning was issued to all firms, we should expect that this intervention would have differentially affected firms' willingness to lower their ERRs in the

\footnotetext{
${ }^{9}$ I also included the annual average institutional holdings in the industry, excluding the focal firm, for each type of institutional investor as a second IV. Prior research has documented a positive correlation between firm-level institutional holdings and industry level institutional holdings (Choi \& Sias, 2009; David et al., 2010), however, the average level of institutional holdings in each firm's industry is plausibly exogenous to the focal firm's ERR. These instruments, however, were not significant in the first-stage model.
} 
years following 2002 based on whether they had an ERR over 9\% in 2002. As Figures 1 and 2

show, there was a marked decline after 2002 in the propensity for firms in my sample to maintain an ERR over 9\%, and the rate of decline in ERRs for firms with a high ERR was steeper. ${ }^{10}$

$$
\begin{aligned}
& \text { [--- Insert Figure } 1 \text { about here ---] } \\
& \text { [--- Insert Figure } 2 \text { about here ---] }
\end{aligned}
$$

To examine whether the relationships between the hypothesized covariates and ERRs were sensitive to this change, I used a triple-differences (i.e., difference-in-difference-indifference) design. Specifically, I examined the difference in the observed relationship between the bank ownership, public pension fund ownership, and finance CEOs (third differences, respectively) on the one hand and ERRs on the other after the treatment (Post-SEC Warning) for firms that had and did not have an ERR over 9\% (High ERR) in 2002. ${ }^{11}$ The results of the 2SLS models are presented in Models 8 through 12 in Table 5.

\section{[--- Insert Table 5 about here ---]}

In Model 8, I regressed onto firms’ ERRs all control variables and a dummy code for the post-SEC warning, a dummy variable indicating whether a firm had a high ERR in 2002, and an interaction of these variables. As expected, the results indicate that after 2002, ERRs decreased significantly and this effect was greater for firms that had a high ERR in 2002, indicating that the policy had the effect of lowering ERRs, particularly in firms with high ERRs. In Model 9, I included the triple difference by interacting rates of bank trust ownership with the high ERR and

\footnotetext{
10 There was a second significant policy change regarding pension assumptions in 2003. In that year, FASB issued SFAS 132R, effective for firms with fiscal years ending after December 15, 2003, that required companies to disclose how their pension assets were being invested across four broad investment classes (i.e., equities, bonds, real estate, and other). I cannot rule out the possibility that the effects I show for the SEC warning are not due to firms anticipating SFAS 132R or firms anticipated the SEC warning in 2001 or in early 2002. There are two potential implications. First, if firms anticipated the SEC warning some time during 2001 or early 2002, there would be measurement error in my proxies, thereby reducing the power of my tests. Second, I cannot differentiate the effect of the SEC warning from SFAS 132R. Other studies have shown that SFAS 132R had an effect on ERR changes beyond that of the SEC warning (e.g., Chuk, 2013). However, my goal is not to test the efficacy of a specific intervention but instead examine how my covariates affect the willingness of firms to lower their ERRs in the wake of a set of policy interventions designed to scrutinize more heavily firms’ pension accounting decisions.

${ }^{11}$ I do not include results on unionization, as there were too few unionized firms in my sample with high ERRs in 2002. The results for unionization, which are available upon request, showed no significant effects.
} 
post-SEC warning indicators. The positive and modestly significant coefficient suggests that for firms with a high ERR in 2002, those with higher rates of bank ownership had a less pronounced reaction to the SEC warning. Despite facing a strong incentive to lower their ERRs, firms with higher rates of bank ownership lowered their ERRs to a lesser extent.

In Models 10 through 12, I repeat the same steps for public and company pension fund share ownership and finance CEOs, respectively. In Model 10, there is a positive and significant coefficient for the triple difference with public pension fund ownership, indicating that higher rates of public pension fund ownership led firms with a high ERR in 2002 to respond less aggressively to the SEC warning. In Model 11, the three-way interaction with company pension fund ownership was not significant. However, the significant interaction between company pension fund share ownership and the SEC warning indicates that as the percentage of a firm's equity owned by company pension plans increased, it was more likely to lower its ERR after the SEC warning irrespective of having a high ERR in 2002. In Model 12, I tested the tripledifference for finance CEOs. I interacted the finance CEO, high ERR, and post-SEC warning indicators. Similar to the results for bank trust and public pension fund ownership, firms with a finance CEO and a high ERR in 2002 decreased their ERRs in subsequent years to a lesser degree than did firms with a non-finance CEO.

Though this intervention is not a pure experiment, as a firm’s choice of ERR in 2002 was not exogenous, it allowed me to examine whether institutional ownership and CEO background differentially affected the response of firms with a high ERR in 2002 to the SEC warning. Taken together, these results show that, despite a strong incentive to lower the ERR, executives did so to a lesser degree when their firms had higher rates of ownership by bank trusts and public pension funds and when they had a finance CEO, thereby providing additional insight on the purported causal relationship between these variables and ERRs.

\section{DISCUSSION}


In recent years, a major issue facing many corporations is paying for their past promises. One salient example of this has occurred in the employment relationship, where promises of lifetime employment and post-retirement income have slowly eroded due to factors like technological advancement, globalization, and financial market pressures (Cappelli, 1999). Despite these changing realities, however, many firms still confront these old commitments and their concomitant financial obligations.

We see this dilemma clearly with DB pensions. A DB plan allows firms to remunerate workers in the future for labor exerted in the present. For such plans to work, however, two things are required. First, the worker must believe she will keep her job long enough to receive the maximum return on the benefits. A pension plan, therefore, necessitates an implicit promise of continued employment that incentivizes workers to accept a future benefit in lieu of wages in the present (Lazear, 1986). Second, workers must believe that the money will be there when they retire, which requires that firms have a means through which to pay for these distant benefits with current contributions and the earnings on those contributions. The ERR is a key financial technology that has given firms the ability to accomplish this second goal. Because the ERR is sensitive to manipulation, firm stakeholders are incentivized to influence its value for their advantage. The purpose of this study was to examine whether stakeholder power dynamics and CEO decision-making schemas influenced how executives adjudicated between the demands of two principals with conflicting interests as evidenced by firms’ ERRs on pension assets.

Drawing insights from socio-political theories of the firm, power-dependence perspectives, stakeholder theory, and the literature on corporate governance, I argued that when executives serve as agents to two principals with conflicting interests, power dynamics and executives' functional expertise influence which principal receives priority. The findings provide support for most hypotheses, showing first that a firm’s level of unionization is negatively associated with ERRs. Though the literature has traditionally overlooked the importance of labor 
in corporate governance (Aguilera \& Jackson, 2003), the results here point to the key role employee power plays in affecting corporate decision-making.

The results of most models examining the effect of bank trust and public pension fund ownership showed each was positively associated with firms’ ERRs. Prior research has substantiated that these institutional investors have strong incentives to invest in firms with better current-earnings performance. This set of findings lends support for the claim that when investors with higher fiduciary standards own a greater proportion of a firm’s equity, firm executives seek ways to boost firm earnings by increasing ERRs. The result for public pensions is particularly interesting given that such owners are often characterized as having a longer-term investment horizon and as preferring firm strategies that consider broader stakeholder interests. It is possible, therefore, that the depiction of public pension funds as having a long-term orientation is inaccurate. Bushee (2004) found that, compared to banks, insurance companies, and investment advisors, pension funds have the second highest percentage of short-term investors (30\%) and are tied for the lowest percentage of long-term investors (7\%). His results suggest that the categorization of public pension funds as holding a long-term orientation belies greater complexity in their investment time horizons.

It is also possible that their longer-term orientation is limited to specific situations. Prior studies substantiating that pension funds are patient capital have examined outcomes such as corporate social responsibility (Johnson \& Greening, 1999), international diversification (Tihanyi et al., 2003), and innovation (Hoskisson et al., 2002), all of which represent relatively fundamental changes to a firm’s strategy with an uncertain impact on future earnings. In comparison, ERR changes are largely unrelated to the firm’s operational strategy and lead directly to increased earnings in the present period. Firms and public pension fund managers may see increasing ERRs as a relatively benign strategy that enhances near-term earnings, features that make the firm a more prudent investment and potentially more appealing to such investors. 
My results also show that company pension fund ownership has no significant effect on ERRs. Though one must exercise caution when attempting to draw inferences from null findings, these results may suggest that, at least as it pertains to pension assumptions, other criteria than short-term earnings maximization are considered by such investors. Finally, although agency theory tends to treat agents' interests as uniform, the results here point to the important role played by executive background in affecting those interests. In particular, my findings support the idea that the functional background of a firm's CEO affects how conflicts between stakeholders are resolved, as the interests of CEOs with a background in finance seem more closely aligned with those of investors preferring better current-earnings performance.

This study contributes to organizational theory in two key ways. First, by combining insights from socio-political, stakeholder, and power-dependence theories (Cyert \& March, 1963; Mitchell et al., 1997; Pfeffer \& Salancik, 1978), I present a fuller picture of the manifold and often competing demands CEOs face and how these get resolved. Corporate governance research normally highlights the tensions between shareholders and executives and the various mechanisms used to align their interests. I sought to complement and extend this research by analyzing the impact of stakeholder influence in a context where the interests of the three key organizational stakeholders-employees, shareholders, and executives—were likely to conflict. In particular, because DB pensions grant poorly defined property rights to workers, these pensions are subject to ex post opportunism by executives (Shleifer \& Summers, 1988). By treating employees and shareholders as principals, differentiating shareholders by their fiduciary responsibilities, and considering how the functional expertise of CEOs informs how they adjudicate between employee and shareholder interests, I attempt to answer recent calls for corporate governance research to attend to the complexity associated with managing multiple stakeholders (Tihanyi, Graffin, \& George, 2014).

Second and relatedly, a key challenge in researching how the differing interests of employees and shareholders are resolved is identifying and examining firm-level contexts where 
these conflicts manifest. A handful of noteworthy studies have analyzed such conflicts by studying outcomes such as managerial employment relationships and layoffs (e.g., Goldstein, 2012; Jung, 2014). By extending this work to the study of pension assumptions, I examined a context in which the interests of investors with stronger fiduciary responsibilities and finance CEOs are in conflict with those of workers, yet the conflict is largely unrelated to the operating performance of the firm. To illustrate, we can take the study of layoffs. While the detrimental impact of layoffs on affected workers is palpable, the logic undergirding that decision (even if proven inaccurate) is typically to make the firm more efficient and profitable (Hallock, 2009). Hence, it is difficult to separate the operational impetus for layoffs from their impact on the workforce. Aggressive ERRs, on the other hand, effectively transfer money that would have gone into the retirement plan into firm earnings yet are largely disconnected from the firm's operating performance. Though I cannot discern an executive's intentions behind changing the firm's ERR, the distinction between operational and financial decisions is important because it eliminates some of the confounding factors that might explain an executive's decision to privilege the interests of one stakeholder group over another.

Additionally, this study complements and extends recent research on DB plan participation. Cobb (2015) found that the desire to reduce the financial uncertainty of DB arrangements was a major factor in firms' decisions to decrease the size of their plans. Largescale surveys have suggested that firms' desire to amend their retirement plans is primarily in response to concerns over the volatility of plan costs (Hewitt Associates, 2003; Towers Watson, 2010; U.S. Government Accountability Office, 2008). In this study, I show that employee power, equity ownership structures, and CEO backgrounds help create that uncertainty (Waring, 2012). That is, when the ERR is greater than the actual rate of return, the firm must make up for this shortfall over time with increased contributions. Because higher ERRs make future pension costs more uncertain, this study suggests that stakeholder conflict helps establish the conditions under which firms are motivated to eventually shrink the size of their DB plans. 
This study also contributes to the broader literature on ERRs as an earnings management tool. Prior research on this topic has largely focused on executives’ incentives for amending the rate. In this study, I argue and find support for the claim that employee and shareholder interests, as well as the decision-making schemas of CEOs, are also factors that influence the rate at which a firm sets its ERR. In so doing, this study has implications for policy. Company pension funds hold trillions of dollars in investments and millions of workers currently or in the future will rely on these funds as a key source of post-retirement income. Given the increasing problems faced within the DB pension system in the United States, it is beneficial to know which factors are associated with better or worse management and funding of these plans (Eaton et al., 2014).

\section{Limitations and Future Directions}

One limitation is that I do not have data on other employment rewards such as wages and other fringe benefits. Therefore, it is possible that as firms increase their ERRs, the proceeds are used to remunerate workers in other ways, such as increasing wages or paying for rising health insurance premiums. There is no evidence from the literature on DB plan terminations and freezes that suggests that the altering of firm retirement plans led to greater worker remuneration. Though the compensating differential rationale for ERR increases seems unlikely, I cannot rule it out. Future empirical research can exploit large-scale, matched firm-employee data or singlefirm studies with data on wages and bundles of benefits to determine whether changes to one form of remuneration are met with changes to others.

Second, while a common issue in observational studies of this type, the influence of unionization, equity ownership, and CEO background cannot be assessed directly. Though the patterns in the data largely support the theoretical claims made herein, there are limits on how much information one can infer from these results. Furthermore, though the supplemental analyses help address concerns with endogeneity, they cannot completely rule it out. In the future, researchers can exploit different methodologies such as interviews, ethnographies, and single-firm studies to better elucidate the mechanisms I hypothesized to be driving these results. 
In a similar vein, there is no way to discern the intent behind ERR increases, and it is possible that executives changed the rate for reasons other than to boost earnings. For instance, a CEO could be overly optimistic and believe the firm can outperform historical market returns. Unless these other rationales for increasing the ERR are correlated with my independent variables (e.g., finance CEOs are more optimistic), finding significant results should be more difficult. While I cannot claim with complete certainty that some ERR increases were not motivated by other factors, the effect of an ERR change on pension expenditures and firm earnings is the same irrespective of intent. It also seems reasonable to assume that regardless of motive, executives are aware of the impact that ERR changes have on firm earnings.

\section{CONCLUSION}

One of the primary features of the employment relationship is that it involves the exchange of labor in return for various forms of remuneration. Beginning in earnest after World War II, firms began rewarding workers with deferred compensation, whereby firms set aside funds for the workers' future with a promise of a lifetime wage in post-retirement for work done in the present period. The promises that undergird this relationship have been increasingly challenged, as these obligations have proved burdensome to many organizations. As the ability of shareholders to influence corporate decision-making increased (Useem, 1993) and the ability of employees to do so waned (Western \& Rosenfeld, 2011), executives increasingly have found ways to deal with those problematic obligations in ways that tend to disadvantage employees.

In this study, I examined the factors motivating firms to alter the return assumptions of their pension plans as a way to boost earnings in the present period and shift worker obligations further into the future. By considering how firms react to demands from their employees and investors, as well as how a CEO’s background affects employment outcomes, the research presented here suggests an important role for organizational theory in linking changes in the corporate power structure to practices that directly affect worker and societal welfare. 
Figure 1. Distribution of ERRs by year
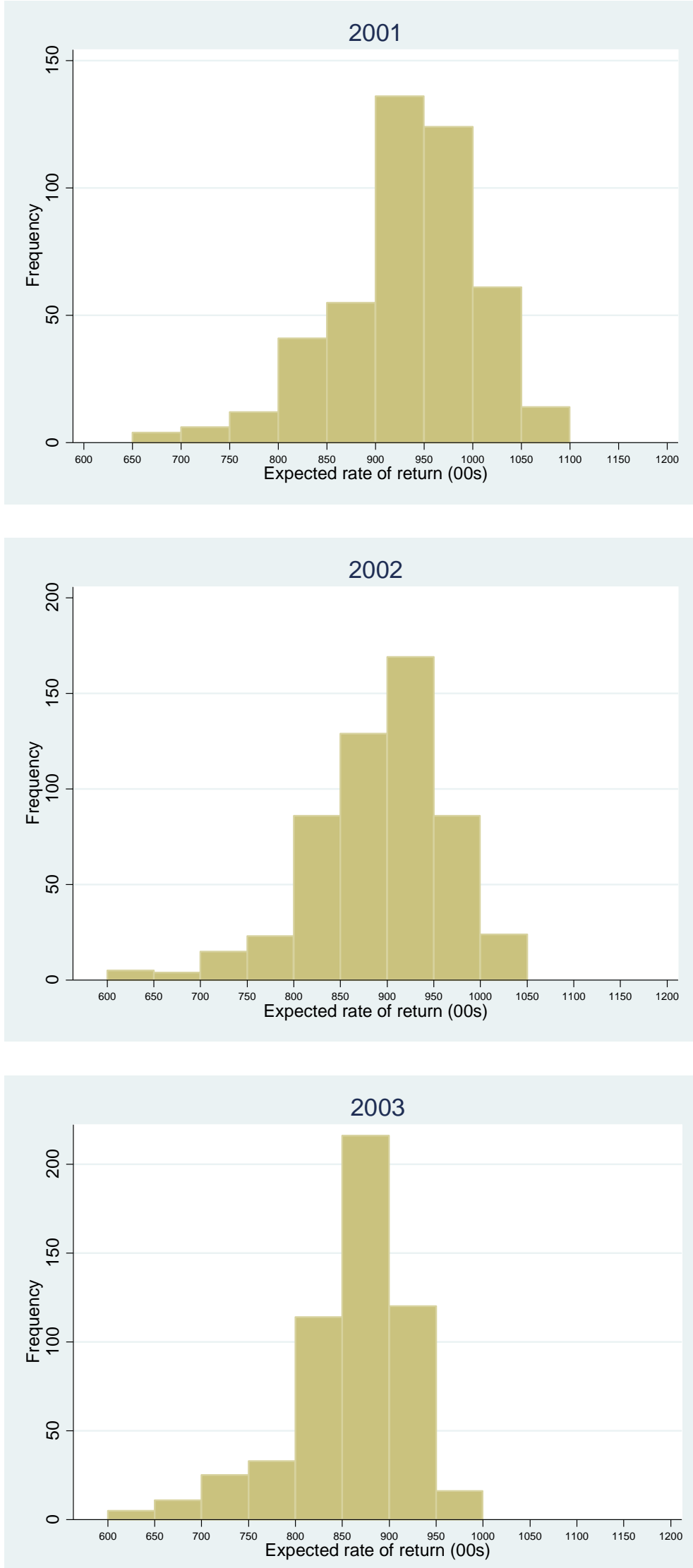
Figure 2. Average ERR, 1999 to 2006

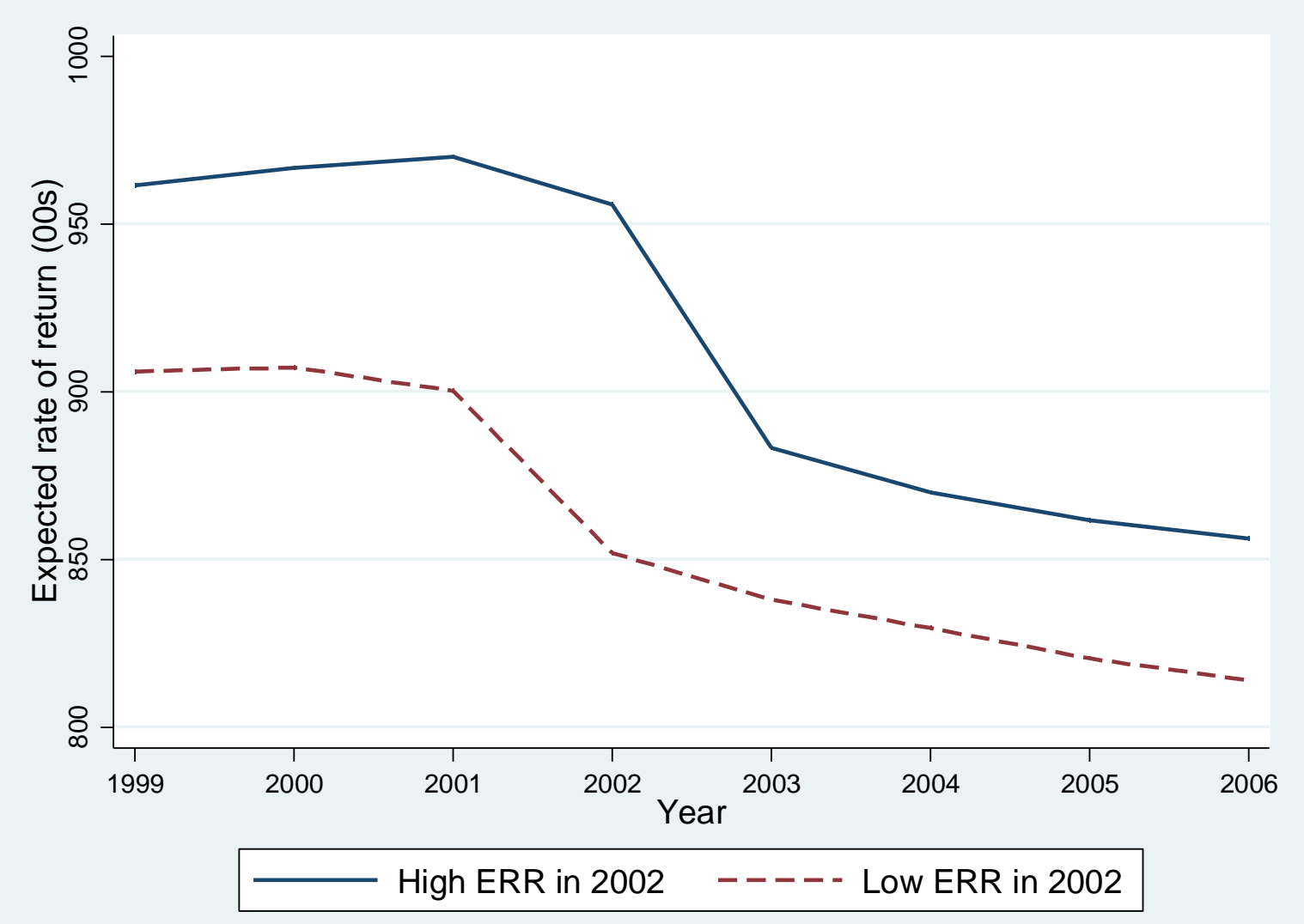


Table 1. Descriptive statistics and correlation matrix, 1992-2006

\begin{tabular}{|c|c|c|c|c|c|c|c|c|c|c|c|c|c|c|}
\hline \multicolumn{2}{|c|}{ Variables } & \multirow{2}{*}{$\begin{array}{l}\text { Mean } \\
890.71\end{array}$} & \multirow{2}{*}{$\begin{array}{l}\text { S.D. } \\
82.81\end{array}$} & & \multirow[t]{2}{*}{2} & \multirow[t]{2}{*}{3} & \multirow[t]{2}{*}{4} & \multirow[t]{2}{*}{5} & \multirow[t]{2}{*}{6} & \multirow[t]{2}{*}{7} & \multirow[t]{2}{*}{8} & \multirow[t]{2}{*}{9} & \multirow[t]{2}{*}{10} & \multirow[t]{2}{*}{11} \\
\hline 1 & Expected rate of retrurn (00s) & & & & & & & & & & & & & \\
\hline 2 & Unionization (\%) & 0.15 & 0.30 & -0.01 & 1 & & & & & & & & & \\
\hline 3 & Bank ownershipt-1 (\%) & 13.64 & 6.86 & 0.00 & -0.06 & 1 & & & & & & & & \\
\hline 4 & Public pension ownership $\mathrm{t}_{\mathrm{t}-1}(\%)$ & 3.15 & 1.89 & 0.09 & 0.00 & 0.25 & 1 & & & & & & & \\
\hline 5 & Company pension ownershipt-1 (\%) & 0.68 & 1.14 & 0.05 & 0.01 & 0.10 & 0.12 & 1 & & & & & & \\
\hline 6 & Insurance co ownershipt-1 (\%) & 5.14 & 4.61 & 0.05 & -0.05 & 0.05 & 0.10 & 0.05 & 1 & & & & & \\
\hline 7 & Investment advisor ownership $\mathrm{t}_{\mathrm{t}-1}(\%)$ & 35.84 & 16.19 & -0.05 & -0.06 & 0.12 & 0.18 & 0.04 & 0.12 & 1 & & & & \\
\hline 8 & CEO Finance & 0.30 & 0.46 & -0.01 & -0.02 & -0.04 & -0.03 & 0.00 & -0.02 & -0.05 & 1 & & & \\
\hline 9 & Total assetst-1 (log) & 8.47 & 1.54 & -0.01 & -0.11 & 0.25 & 0.05 & 0.10 & 0.07 & -0.03 & 0.24 & 1 & & \\
\hline 10 & Revenue growth (\%) & 0.01 & 0.03 & -0.03 & -0.01 & 0.03 & 0.00 & 0.00 & 0.04 & 0.06 & 0.01 & 0.00 & 1 & \\
\hline 11 & Return on equityt-1 (\%) & 11.78 & 31.62 & 0.00 & -0.02 & 0.07 & -0.03 & 0.01 & 0.00 & -0.03 & 0.01 & 0.02 & 0.02 & 1 \\
\hline 12 & Debt-to-assets ratiot-1 (\%) & 22.76 & 15.63 & 0.06 & 0.12 & -0.18 & -0.09 & -0.05 & -0.05 & 0.06 & -0.07 & -0.16 & -0.01 & -0.08 \\
\hline 13 & DB assets (log) & 19.55 & 1.83 & 0.11 & 0.03 & 0.26 & 0.08 & 0.06 & 0.03 & -0.03 & 0.01 & 0.59 & -0.08 & 0.03 \\
\hline 14 & Funding status (\%) & 104.90 & 30.59 & 0.17 & 0.00 & 0.00 & 0.02 & 0.04 & -0.01 & -0.21 & 0.05 & 0.00 & -0.02 & 0.01 \\
\hline 15 & Shareholder rights & 14.04 & 2.63 & -0.05 & 0.02 & -0.14 & -0.15 & -0.05 & 0.01 & -0.15 & -0.03 & 0.08 & 0.01 & 0.00 \\
\hline 16 & CEO tenure & 5.29 & 6.38 & -0.02 & -0.03 & 0.01 & 0.04 & 0.03 & -0.02 & -0.04 & -0.05 & 0.00 & 0.03 & 0.01 \\
\hline 17 & CEO pay from options (\%) & 28.13 & 25.05 & 0.14 & -0.03 & 0.09 & -0.01 & 0.04 & 0.11 & 0.13 & 0.01 & 0.11 & 0.01 & 0.03 \\
\hline 18 & Industry Mergerst-1 & 6.13 & 7.60 & 0.00 & -0.03 & 0.05 & -0.06 & 0.01 & 0.00 & -0.02 & 0.10 & 0.29 & 0.03 & 0.04 \\
\hline 19 & Missed earnings & 0.44 & 0.50 & 0.01 & 0.01 & -0.10 & -0.02 & -0.04 & -0.04 & 0.03 & -0.01 & -0.03 & -0.14 & -0.06 \\
\hline 20 & Avoid missed earnings & 0.03 & 0.17 & 0.07 & 0.04 & 0.00 & -0.01 & -0.01 & -0.03 & -0.05 & 0.01 & 0.00 & 0.02 & 0.01 \\
\hline 21 & Industry average ERRt-1 (\%) & 8.97 & 0.43 & 0.34 & 0.05 & -0.07 & 0.06 & 0.06 & 0.05 & -0.11 & -0.03 & -0.19 & -0.07 & -0.01 \\
\hline
\end{tabular}

\begin{tabular}{|c|c|c|c|c|c|c|c|c|c|c|c|}
\hline \multicolumn{2}{|c|}{ Variables } & 12 & 13 & 14 & 15 & 16 & 17 & 18 & 19 & 20 & 21 \\
\hline 12 & Debt-to-assets ratiot-1 (\%) & 1 & & & & & & & & & \\
\hline 13 & DB assets (log) & -0.06 & 1 & & & & & & & & \\
\hline 14 & Funding status (\%) & -0.09 & 0.13 & 1 & & & & & & & \\
\hline 15 & Shareholder rights & 0.03 & -0.01 & -0.03 & 1 & & & & & & \\
\hline 16 & CEO tenure & -0.01 & -0.10 & 0.03 & 0.05 & 1 & & & & & \\
\hline 17 & CEO pay from options (\%) & -0.09 & 0.08 & 0.00 & -0.05 & -0.08 & 1 & & & & \\
\hline 18 & Industry Mergers $\mathrm{t}_{\mathrm{t}-1}$ & -0.06 & 0.20 & 0.09 & -0.01 & -0.02 & 0.14 & 1 & & & \\
\hline 19 & Missed earnings & 0.13 & 0.03 & -0.01 & 0.02 & -0.03 & 0.05 & 0.02 & 1 & & \\
\hline 20 & Avoid missed earnings & 0.00 & 0.06 & 0.06 & 0.02 & -0.03 & -0.02 & 0.01 & -0.15 & 1 & \\
\hline 21 & Industry average $\mathrm{ERR}_{\mathrm{t}-1}(\%)$ & 0.06 & -0.06 & 0.27 & -0.03 & 0.03 & 0.18 & -0.03 & 0.06 & 0.02 & 1 \\
\hline
\end{tabular}


Table 2. Fixed-effects regression on ERRs on pension assets, 1992-2006

\begin{tabular}{|c|c|c|c|}
\hline Variables & M1 & M2 & M3 \\
\hline Unionization (\%) & $\begin{array}{c}-24.182 * * \\
(8.192)\end{array}$ & & $\begin{array}{c}-24.123^{* *} \\
(9.254)\end{array}$ \\
\hline Bank ownershipt-1 (\%) & $\begin{array}{l}0.319+ \\
(0.163)\end{array}$ & & $\begin{array}{c}0.472 * \\
(0.185)\end{array}$ \\
\hline Public pension ownershipt-1 (\%) & $\begin{array}{c}1.741^{* * *} \\
(0.489)\end{array}$ & & $\begin{array}{l}0.936^{*} \\
(0.470)\end{array}$ \\
\hline Company pension ownershipt-1 (\%) & $\begin{array}{c}-1.632 * \\
(0.780)\end{array}$ & & $\begin{array}{l}-1.179 \\
(0.835)\end{array}$ \\
\hline Insurance co ownershipt-1 (\%) & $\begin{array}{l}-0.145 \\
(0.249)\end{array}$ & & $\begin{array}{c}0.166 \\
(0.286)\end{array}$ \\
\hline Investment advisor ownership $\mathrm{p}_{\mathrm{t}-1}(\%)$ & $\begin{array}{l}0.145^{+} \\
(0.078)\end{array}$ & & $\begin{array}{c}0.099 \\
(0.095)\end{array}$ \\
\hline CEO Finance & $\begin{array}{l}4.121+ \\
(2.307)\end{array}$ & & $\begin{array}{l}5.442^{*} \\
(2.535)\end{array}$ \\
\hline Total assetst-1 $(\log )$ & & $\begin{array}{c}3.362 \\
(2.287)\end{array}$ & $\begin{array}{c}3.495 \\
(2.319)\end{array}$ \\
\hline Revenue growth (\%) & & $\begin{array}{c}-15.928 \\
(30.873)\end{array}$ & $\begin{array}{l}-23.383 \\
(30.898)\end{array}$ \\
\hline Return on equityt-1 (\%) & & $\begin{array}{c}-0.048+ \\
(0.025)\end{array}$ & $\begin{array}{l}-0.048+ \\
(0.025)\end{array}$ \\
\hline Debt-to-assets ratio ${ }_{t-1}(\%)$ & & $\begin{array}{c}0.031 \\
(0.095)\end{array}$ & $\begin{array}{c}0.040 \\
(0.095)\end{array}$ \\
\hline DB assets (log) & & $\begin{array}{l}-1.083 \\
(1.531)\end{array}$ & $\begin{array}{l}-1.191 \\
(1.533)\end{array}$ \\
\hline Funding status (\%) & & $\begin{array}{l}0.074+ \\
(0.043)\end{array}$ & $\begin{array}{c}0.066 \\
(0.043)\end{array}$ \\
\hline Shareholder rights & & $\begin{array}{c}-4.364 * * * \\
(0.793)\end{array}$ & $\begin{array}{c}-3.992 * * * \\
(0.804)\end{array}$ \\
\hline CEO tenure & & $\begin{array}{c}0.443^{* *} \\
(0.159)\end{array}$ & $\begin{array}{c}0.448^{* *} \\
(0.159)\end{array}$ \\
\hline CEO pay from options (\%) & & $\begin{array}{c}0.016 \\
(0.037)\end{array}$ & $\begin{array}{c}0.014 \\
(0.037)\end{array}$ \\
\hline Industry mergers $\mathrm{t}_{-1}$ & & $\begin{array}{c}0.118 \\
(0.142)\end{array}$ & $\begin{array}{c}0.093 \\
(0.143)\end{array}$ \\
\hline Missed earnings & & $\begin{array}{c}1.960 \\
(1.654)\end{array}$ & $\begin{array}{c}2.032 \\
(1.657)\end{array}$ \\
\hline Avoid missed earnings & & $\begin{array}{c}23.045^{* * *} \\
(3.796)\end{array}$ & $\begin{array}{c}23.096 * * * \\
(3.793)\end{array}$ \\
\hline Industry average $\mathrm{ERR}_{\mathrm{t}-1}(\%)$ & & $\begin{array}{c}11.495^{* * *} \\
(3.231)\end{array}$ & $\begin{array}{c}10.970 * * * \\
(3.234)\end{array}$ \\
\hline Constant & $\begin{array}{c}915.984^{* * *} \\
(2.602) \\
\end{array}$ & $\begin{array}{c}983.859 * * * \\
(12.062) \\
\end{array}$ & $\begin{array}{c}975.188^{* * *} \\
(12.326) \\
\end{array}$ \\
\hline Observations & 6,803 & 5,619 & 5,610 \\
\hline Firms & 708 & 658 & 658 \\
\hline Year dummies & Yes & Yes & Yes \\
\hline R-squared & 0.31 & 0.33 & 0.36 \\
\hline
\end{tabular}

$* * * \mathrm{p}<0.001, * * \mathrm{p}<0.01,{ }^{*} \mathrm{p}<0.05,+\mathrm{p}<0.10$. Tests are two-tailed Standard errors in parentheses 
Table 3. Error correction regression model on ERRs on pension assets, 1993-2006

\begin{tabular}{|c|c|c|}
\hline \multirow[b]{2}{*}{ Variables } & \multicolumn{2}{|l|}{ M4 } \\
\hline & Coefficient & St Error \\
\hline Unionization (\%) & $-20.358 * * *$ & (1.954) \\
\hline$\Delta$ Unionization (\%) & $-33.909 * * *$ & $(8.985)$ \\
\hline Bank ownership (\%) & $0.695^{* * *}$ & $(0.102)$ \\
\hline$\Delta$ Bank ownership (\%) & $0.775 * * *$ & $(0.163)$ \\
\hline Public pension ownership (\%) & $0.489 * * *$ & $(0.367)$ \\
\hline$\Delta$ Public pension ownership (\%) & $1.749 * * *$ & $(0.526)$ \\
\hline Company pension ownership (\%) & $-2.639 * * *$ & $(0.483)$ \\
\hline$\Delta$ Company pension ownership (\%) & $-2.432 * * *$ & $(0.473)$ \\
\hline CEO Finance & $3.608 * * *$ & $(1.353)$ \\
\hline$\Delta$ CEO Finance & $19.606^{* * *}$ & $(2.782)$ \\
\hline Constant & $997.012 * * *$ & $(33.784)$ \\
\hline Observations & 5,772 & \\
\hline Adjusted R-squared & 0.770 & \\
\hline
\end{tabular}

*** $\mathrm{p}<0.001,{ }^{* *} \mathrm{p}<0.01, * \mathrm{p}<0.05,+\mathrm{p}<0.10$. Tests are two-tailed

Panel-corrected standard errors in parentheses 
Table 4. Two-stage least squares regression on ERRs on pension assets, 1992-2006

\begin{tabular}{|c|c|c|c|}
\hline Variables & M5 & M6 & M7 \\
\hline Unionization (\%) & $\begin{array}{l}-13.199 \\
(13.596)\end{array}$ & $\begin{array}{c}-1.960 \\
(17.597) \\
\end{array}$ & $\begin{array}{c}-51.925^{* *} \\
(19.347)\end{array}$ \\
\hline Analystst-1 & $\begin{array}{c}0.106 * * * \\
(0.169) \\
\end{array}$ & $\begin{array}{c}\text { First stage } \\
0.025^{* * *} \\
(0.005)\end{array}$ & $\begin{array}{c}0.013 * * \\
(0.004)\end{array}$ \\
\hline Bank ownershipt-1 (\%) & $\begin{array}{l}6.565^{*} \\
(2.773)\end{array}$ & & \\
\hline Public pension ownershipt-1 (\%) & & $\begin{array}{l}27.649 * \\
(12.513)\end{array}$ & \\
\hline Company pension ownershipt-1 (\%) & & & $\begin{array}{c}21.127 \\
(25.246)\end{array}$ \\
\hline CEO Finance & $\begin{array}{c}3.465 \\
(3.142)\end{array}$ & $\begin{array}{c}2.477 \\
(3.784)\end{array}$ & $\begin{array}{l}15.208^{*} \\
(6.073)\end{array}$ \\
\hline Total assetst 1 (log) & $\begin{array}{c}-0.748 \\
(3.227)\end{array}$ & $\begin{array}{l}-6.397 \\
(5.090)\end{array}$ & $\begin{array}{l}-4.677 \\
(5.224)\end{array}$ \\
\hline Revenue growth (\%) & $\begin{array}{l}-11.141 \\
(38.445)\end{array}$ & $\begin{array}{l}-53.465 \\
(38.371)\end{array}$ & $\begin{array}{l}-22.564 \\
(40.054)\end{array}$ \\
\hline Return on equityt-1 (\%) & $\begin{array}{c}-0.049+ \\
(0.028)\end{array}$ & $\begin{array}{l}-0.000 \\
(0.040)\end{array}$ & $\begin{array}{l}-0.084^{*} \\
(0.037)\end{array}$ \\
\hline Debt-to-assets ratio ${ }_{t-1}(\%)$ & $\begin{array}{c}0.225 \\
(0.146)\end{array}$ & $\begin{array}{l}-0.089 \\
(0.131)\end{array}$ & $\begin{array}{l}-0.129 \\
(0.160)\end{array}$ \\
\hline DB assets (log) & $\begin{array}{l}-4.293^{*} \\
(2.173)\end{array}$ & $\begin{array}{c}0.070 \\
(2.248)\end{array}$ & $\begin{array}{l}-1.950 \\
(2.089)\end{array}$ \\
\hline Funding status (\%) & $\begin{array}{c}0.049 \\
(0.067)\end{array}$ & $\begin{array}{c}0.046 \\
(0.076)\end{array}$ & $\begin{array}{c}0.113 \\
(0.092)\end{array}$ \\
\hline Shareholder rights & $\begin{array}{l}-2.996^{*} \\
(1.313)\end{array}$ & $\begin{array}{l}-1.560 \\
(1.759)\end{array}$ & $\begin{array}{l}-3.256^{*} \\
(1.417)\end{array}$ \\
\hline CEO tenure & $\begin{array}{c}0.234 \\
(0.194)\end{array}$ & $\begin{array}{c}0.198 \\
(0.220)\end{array}$ & $\begin{array}{c}0.131 \\
(0.274)\end{array}$ \\
\hline CEO pay from options (\%) & $\begin{array}{l}-0.003 \\
(0.046)\end{array}$ & $\begin{array}{c}0.034 \\
(0.049)\end{array}$ & $\begin{array}{l}-0.012 \\
(0.053)\end{array}$ \\
\hline Industry Mergers $\mathrm{t}_{-1}$ & $\begin{array}{c}0.007 \\
(0.149)\end{array}$ & $\begin{array}{l}-0.111 \\
(0.191)\end{array}$ & $\begin{array}{l}-0.593 \\
(0.481)\end{array}$ \\
\hline Missed earnings & $\begin{array}{c}0.211 \\
(2.079)\end{array}$ & $\begin{array}{c}0.373 \\
(2.301)\end{array}$ & $\begin{array}{c}1.053 \\
(2.317)\end{array}$ \\
\hline Avoid missed earnings & $\begin{array}{c}24.770^{* * *} \\
(4.457)\end{array}$ & $\begin{array}{c}25.245^{* * *} \\
(4.715)\end{array}$ & $\begin{array}{c}19.481^{* * *} \\
(4.636)\end{array}$ \\
\hline Industry average $\mathrm{ERR}_{\mathrm{t}-1}(\%)$ & $\begin{array}{c}10.436^{*} \\
(4.453) \\
\end{array}$ & $\begin{array}{c}10.289 * \\
(4.633) \\
\end{array}$ & $\begin{array}{c}12.254^{*} \\
(5.284) \\
\end{array}$ \\
\hline Observations & 5,554 & 5,550 & 5,550 \\
\hline Firms & 628 & 628 & 628 \\
\hline Year dummies & Yes & Yes & Yes \\
\hline
\end{tabular}

*** $\mathrm{p}<0.001,{ }^{* *} \mathrm{p}<0.01,{ }^{*} \mathrm{p}<0.05,+\mathrm{p}<0.10$. Tests are two-tailed

Standard errors in parentheses 
Table 5. Triple-difference regression on ERRs on pension assets, 1992-2006

\begin{tabular}{|c|c|c|c|c|c|}
\hline Variables & M8 & M9 & M10 & M11 & M12 \\
\hline Post-SEC Warning & $\begin{array}{l}-85.696 * * * \\
(6.295)\end{array}$ & $\begin{array}{c}-86.493^{* * *} \\
(6.717)\end{array}$ & $\begin{array}{l}-87.915^{* * *} \\
\quad(6.710)\end{array}$ & $\begin{array}{l}-95.551^{* * *} \\
(6.719)\end{array}$ & $\begin{array}{c}-89.565^{* * *} \\
(6.817)\end{array}$ \\
\hline High ERR & $\begin{array}{l}-22.349+ \\
(13.116)\end{array}$ & $\begin{array}{l}-20.777 \\
(13.175)\end{array}$ & $\begin{array}{l}-21.516 \\
(13.205)\end{array}$ & $\begin{array}{r}-23.843+ \\
(13.116)\end{array}$ & $\begin{array}{l}-18.617 \\
(13.319)\end{array}$ \\
\hline High ERR x Post-SEC warning & $\begin{array}{l}-20.891 * * * \\
(3.446)\end{array}$ & $\begin{array}{l}-20.898^{* * *} \\
(4.153)\end{array}$ & $\begin{array}{l}-26.727 * * * \\
(4.245)\end{array}$ & $\begin{array}{l}-18.597 * * * \\
(4.200)\end{array}$ & $\begin{array}{c}-26.027 * * * \\
(4.243)\end{array}$ \\
\hline Unionization (\%) & & $\begin{array}{c}-25.176^{* *} \\
(9.219)\end{array}$ & $\begin{array}{c}-26.426^{* *} \\
(9.243)\end{array}$ & $\begin{array}{c}-18.562^{*} \\
(9.251)\end{array}$ & $\begin{array}{c}-25.743^{* *} \\
(9.231)\end{array}$ \\
\hline Bank ownershipt-1 (\%) & & $\begin{array}{c}1.156^{* * * *} \\
(0.235)\end{array}$ & $\begin{array}{l}0.423^{*} \\
(0.185)\end{array}$ & $\begin{array}{l}0.375^{*} \\
(0.183)\end{array}$ & $\begin{array}{l}0.405^{*} \\
(0.184)\end{array}$ \\
\hline Bank ownership x High ERR & & $\begin{array}{c}-1.446^{* *} \\
(0.439)\end{array}$ & & & \\
\hline Bank ownership x Post-SEC warning & & $\begin{array}{c}-1.584^{* * *} \\
(0.350)\end{array}$ & & & \\
\hline Bank ownership x High ERR x Post-SEC warning & & $\begin{array}{l}1.017+ \\
(0.555)\end{array}$ & & & \\
\hline Public pension ownershipt-1 (\%) & & $\begin{array}{l}1.179 * \\
(0.577)\end{array}$ & $\begin{array}{l}1.324+ \\
(0.676)\end{array}$ & $\begin{array}{l}1.152 * \\
(0.575)\end{array}$ & $\begin{array}{l}1.032+ \\
(0.577)\end{array}$ \\
\hline Public pension ownership x High ERR & & & $\begin{array}{c}-0.942 \\
(1.230)\end{array}$ & & \\
\hline Public pension ownership x Post-SEC warning & & & $\begin{array}{c}-2.741 \\
(2.115)\end{array}$ & & \\
\hline $\begin{array}{l}\text { Public pension ownership x High ERR x Post- } \\
\text { SEC warning }\end{array}$ & & & $\begin{array}{l}9.558 * \\
(3.839)\end{array}$ & & \\
\hline Company pension ownershipt-1 (\%) & & $\begin{array}{l}-1.253 \\
(0.829)\end{array}$ & $\begin{array}{l}-1.298 \\
(0.832)\end{array}$ & $\begin{array}{c}0.042 \\
(0.939)\end{array}$ & $\begin{array}{l}-1.267 \\
(0.831)\end{array}$ \\
\hline Company pension ownership x High ERR & & & & $\begin{array}{c}0.259 \\
(2.173)\end{array}$ & \\
\hline Company pension ownership x Post-SEC warning & & & & $\begin{array}{l}-15.708^{* * *} \\
(2.454)\end{array}$ & \\
\hline $\begin{array}{l}\text { Company pension ownership x High ERR x Post- } \\
\text { SEC warning }\end{array}$ & & & & $\begin{array}{c}4.942 \\
(5.388)\end{array}$ & \\
\hline CEO Finance & & $\begin{array}{l}4.991^{*} \\
(2.513)\end{array}$ & $\begin{array}{l}5.154^{*} \\
(2.521)\end{array}$ & $\begin{array}{l}4.622+ \\
(2.511)\end{array}$ & $\begin{array}{c}5.001 \\
(3.278)\end{array}$ \\
\hline CEO Finance $x$ High ERR & & & & & $\begin{array}{c}-4.593 \\
(6.224)\end{array}$ \\
\hline CEO Finance x Post-SEC warning & & & & & $\begin{array}{l}-1.221 \\
(4.338)\end{array}$ \\
\hline CEO Finance $\mathrm{x}$ High ERR $\mathrm{x}$ Post-SEC warning & & & & & $\begin{array}{l}16.852^{*} \\
(7.756)\end{array}$ \\
\hline Constant & $\begin{array}{c}987.642 * * * \\
(12.384)\end{array}$ & $\begin{array}{c}976.545 * * * \\
(12.626) \\
\end{array}$ & $\begin{array}{c}979.852 * * * \\
(12.640)\end{array}$ & $\begin{array}{c}978.847 * * * \\
(12.588) \\
\end{array}$ & $\begin{array}{c}978.905^{* * *} \\
(12.675)\end{array}$ \\
\hline Observations & 5,606 & 5,597 & 5,597 & 5,597 & 5,597 \\
\hline Firms & 658 & 658 & 658 & 658 & 658 \\
\hline Year dummies & Yes & Yes & Yes & Yes & Yes \\
\hline R-squared & 0.357 & 0.365 & 0.362 & 0.367 & 0.362 \\
\hline
\end{tabular}

*** $\mathrm{p}<0.001,{ }^{* *} \mathrm{p}<0.01,{ }^{*} \mathrm{p}<0.05,+\mathrm{p}<0.10$. Tests are two-tailed

Standard errors in parentheses 


\section{REFERENCES}

Abarbanell, J. S., Bushee, B. J., \& Raedy, J. S. 2003. Institutional investor preferences and price pressure: The case of corporate spin-offs. Journal of Business, 76(2): 233-261.

Adams, J. 1996. Principals and agents, colonialists and company men: The decay of colonial control in the Dutch East Indies. American Sociological Review, 61(1): 12-28.

Agle, B. R., Mitchell, R. K., \& Sonnenfeld, J. A. 1999. Who matters to CEOs? An investigation of stakeholder attributes and salience, corporate performance, and CEO values. Academy of Management Journal, 42(5): 507-525.

Aguilera, R. V., Filatotchev, I., Gospel, H., \& Jackson, G. 2008. An organizational approach to comparative corporate governance: Costs, contingencies, and complementarities. Organization Science, 19(3): 475-492.

Aguilera, R. V., \& Jackson, G. 2003. The cross-national diversity of corporate governance: Dimensions and determinants. Academy of Management Review, 28(3): 447-465.

An, H., Lee, Y. W., \& Zhang, T. 2014. Do corporations manage earnings to meet/exceed analyst forecasts? Evidence from pension plan assumption changes. Review of Accounting Studies, 19(2): 698-735.

Aoki, M. 2001. Toward a comparative institutional analysis. Cambridge, MA: MIT Press.

Arthurs, J. D., Hoskisson, R. E., Busenitz, L. W., \& Johnson, R. A. 2008. Managerial agents watching other agents: Multiple agency conflicts regarding underpricing in IPO firms. Academy of Management Journal, 51(2): 277-294.

Asher, C. C., Mahoney, J. M., \& Mahoney, J. T. 2005. Towards a Property Rights Foundation for a Stakeholder Theory of the Firm. Journal of Management and Governance, 9: 5-32.

Badrinath, S. G., Gay, G. D., \& Kale, J. R. 1989. Patterns of Institutional Investment, Prudence, and the Managerial Safety-Net Hypothesis. Journal of Risk and Insurance, 56(4): 605629.

Barnard, C. I. 1938. Functions of the Executive. Cambridge, MA: Harvard University Press.

Bascle, G. 2008. Controlling for endogeneity with instrumental variables in strategic management research. Strategic Organization, 6(3): 285-327.

Benmelech, E., Bergman, N., \& Enriquez, R. 2012. Negotiating with Labor Unions Under Financial Distress. Review of Corporate Financial Studies, 1: 28-67.

Bergstresser, D., Desai, M. A., \& Rauh, J. 2006. Earnings manipulation, pension assumptions, and managerial investment decisions. Quarterly Journal of Economics, 121(1): 157-195.

Bernheim, B. D., \& Whinston, M. D. 1986. Common Agency. Econometrica, 54(4): 923-942.

Bidwell, M. J. 2013. What Happened to Long-Term Employment? The Role of Worker Power and Environmental Turbulence in Explaining Declines in Worker Tenure. Organization Science, 24(4): 1061-1082.

Blair, M. M., \& Roe, M. J. (Eds.). 1999. Employees and corporate governance. Washington, D.C.: The Brookings Institute.

Blair, M. M., \& Stout, L. A. 1999. A team production theory of corporate law. Virginia Law Review, 85(2): 247-328.

Blouin, J., Core, J. E., \& Guay, W. 2010. Have the tax benefits of debt been overestimated? Journal of Financial Economics, 98(2): 195-213.

Budros, A. 2000. Organizational types and organizational innovation: Downsizing among industrial, financial, and utility firms. Sociological Forum, 15(2): 273-306.

Buffett, W., \& Loomis, C. 2001. Warren Buffett on the Stock Market [electronic version], Fortune. 
Bundy, J., Shropshire, C., \& Buchholtz, A. K. 2013. Strategic Cognition and Issue Salience: Toward an Explanation of Firm Responsiveness to Stakeholder Concerns. Academy of Management Review, 38(3): 352-376.

Bushee, B. J. 1998. The influence of institutional investors on myopic R\&D investment behavior. Accounting Review, 73(3): 305-333.

Bushee, B. J. 2001. Do institutional investors prefer near-term earnings over long-run value? . Contemporary Accounting Research, 18: 207-246.

Cappelli, P. H. 1999. The New Deal at Work: Managing the Market-Driven Workforce. Boston, MA: Harvard University Press.

Chang, S. J. 2003. Ownership structure, expropriation, and performance of group-affiliated companies in Korea. Academy of Management Journal, 46(2): 238-253.

Chen, G., Luo, S., Tang, Y., \& Tong, J. Y. 2015. Passing Probation: Earnings Management by Interim CEOs and Its Effect on Their Promotion Prospects. Academy of Management Journal, 58(5): 1389-1418.

Choi, N., \& Sias, R. W. 2009. Institutional industry herding. Journal of Financial Economics, 94(3): 469-491.

Chuk, E. C. 2013. Economic Consequences of Mandated Accounting Disclosures: Evidence from Pension Accounting Standards. Accounting Review, 88(2): 395-427.

Chung, R., Firth, M., \& Kim, J.-B. 2002. Institutional monitoring and opportunistic earnings management. Journal of Corporate Finance, 8(1): 29-48.

Cobb, J. A. 2015. Risky business: Firms' shifting of retirement risk and the decline of defined benefit pension plans. Organization Science, 26(5): 1332-1350.

Coff, R. W. 1999. When competitive advantage doesn't lead to performance: The resource-based view and stakeholder bargaining power. Organization Science, 10(2): 119-133.

Comprix, J., \& Muller, K. A. 2011. Pension plan accounting estimates and the freezing of defined benefit pension plans. Journal of Accounting \& Economics, 51(1-2): 115-133.

Connelly, B. L., Hoskisson, R. E., Tihanyi, L., \& Certo, S. T. 2010. Ownership as a Form of Corporate Governance. Journal of Management Studies, 47(8): 1561-1589.

Connelly, B. L., Tihanyi, L., Certo, S. T., \& Hitt, M. A. 2010. Marching to the Beat of Different Drummers: The Influence of Institutional Investors on Competitive Actions. Academy of Management Journal, 53(4): 723-742.

Cornett, M. M., Marcus, A. J., Saunders, A., \& Tehranian, H. 2007. The impact of institutional ownership on corporate operating performance. Journal of Banking \& Finance, 31(6): 1771-1794.

Coronado, J., Mitchell, O. S., Sharpe, S. A., \& Nesbitt, S. B. 2008. Footnotes aren't enough: the impact of pension accounting on stock values. Journal of Pension Economics \& Finance, 7(3): 257-276.

Coronado, J., \& Sharpe, S. A. 2003. Did pension plan accounting contribute to a stock market bubble? Brookings Papers on Economic Activity(1): 323-371.

Custodio, C., \& Metzger, D. 2014. Financial expert CEOs: CEO's work experience and firm's financial policies. Journal of Financial Economics, 114(1): 125-154.

Cyert, R. M., \& March, J. G. 1963. A Behavioral Theory of the Firm. Englewood Cliffs, NJ: Prentice-Hall.

Dalton, D. R., Hitt, M. A., Certo, S. T., \& Dalton, C. M. 2007. The fundamental agency problem and its mitigation: Independence, equity, and the market for corporate control. Academy of Management Annals, 1: 1-65. 
David, P., Kochhar, R., \& Levitas, E. 1998. The effect of institutional investors on the level and mix of CEO compensation. Academy of Management Journal, 41(2): 200-208.

David, P., O'Brien, J. P., Yoshikawa, T., \& Delios, A. 2010. Do Shareholders or Stakeholders Appropriate the Rents from Corporate Diversification? The Influence of Ownership Structure. Academy of Management Journal, 53(3): 636-654.

Davis, G. F. 2005. New directions in corporate governance. Annual Review of Sociology, 31: 143-162.

Davis, G. F., \& Stout, S. K. 1992. Organization Theory and the Market for Corporate Control: A Dynamic Analysis of the Characteristics of Large Takeover Targets, 1980-1990. Administrative Science Quarterly, 37(4): 305-633.

Dearborn, D. C., \& Simon, H. A. 1958. Selective Perception: A Note on the Departmental Identifications of Executives. Sociometry, 21(2): 140-144.

Del Guercio, D. 1996. The distorting effect of the prudent-man laws on institutional equity investments. Journal of Financial Economics, 40(1): 31-62.

Dencker, J. C. 2009. Relative Bargaining Power, Corporate Restructuring, and Managerial Incentives. Administrative Science Quarterly, 54(3): 453-485.

Dencker, J. C., Joshi, A., \& Martocchio, J. J. 2009. Employee benefits as context for intergenerational conflict. Human Resource Management Review, 17(2): 208-220.

Dikolli, S. S., Mayew, W. J., \& Nanda, D. 2014. CEO tenure and the performance-turnover relation. Review of Accounting Studies, 19(1): 281-327.

Dodd, E. M., Jr. . 1932. For whom are corporate managers trustees? Harvard Law Review, 45(7): 1145-1163.

Eaton, T. V., Nofsinger, J. R., \& Varma, A. 2014. Institutional Investor Ownership and Corporate Pension Transparency. Financial Management, 43(3): 603-630.

Emerson, R. M. 1962. Power-Dependence Relations. American Sociological Review, 27(1): 3141.

Fama, E. F. 1980. Agency Problems and the Theory of the Firm. Journal of Political Economy, 88(2): 288-307.

Filatotchev, I., \& Toms, S. 2006. Corporate governance and financial constraints on strategic turnarounds. Journal of Management Studies, 43(3): 407-433.

Finkelstein, S., Hambrick, D. C., \& Cannella, A. A. 2009. Strategic Leadership: Theory and Research on Executives, Top Management Teams, and Boards. Oxford: Oxford University Press.

Fiss, P. C., \& Zajac, E. J. 2004. The diffusion of ideas over contested terrain: The (non)adoption of a shareholder value orientation among German firms. Administrative Science Quarterly, 49(4): 501-534.

Fligstein, N. 1990. The Transformation of Corporate Control. Cambridge, Massachussetts: Harvard University Press.

Fligstein, N. 1991. The structural transformation of American industry: An institutional account of the causes of diversification in the largest firms, 1919-1979. In W. W. Powell, \& P. J. DiMaggio (Eds.), The New Institutionalism in Organizational Analysis: 311-336. Chicago, IL: The University of Chicago Press.

Fligstein, N., \& Shin, T. 2007. Shareholder value and the transformation of the US economy, 1984-2000. Sociological Forum, 22(4): 399-424.

Franzoni, F., \& Marin, J. M. 2006. Pension plan funding and stock market efficiency. Journal of Finance, 61(2): 921-956.

Freeman, R. B., \& Medoff, J. L. 1984. What Do Unions Do? New York: Basic Books. 
Freeman, R. E. 1984. Strategic management: A stakeholder approach. Boston: Pitman.

Goldberg, V. P. 1980. Bridges over Contested Terrain - Exploring the Radical Account of the Employment Relationship. Journal of Economic Behavior \& Organization, 1(3): 249274.

Goldstein, A. 2012. Revenge of the Managers: Labor Cost-Cutting and the Paradoxical Resurgence of Managerialism in the Shareholder Value Era, 1984 to 2001. American Sociological Review, 77(2): 268-294.

Gompers, P. A., Ishii, J., \& Metrick, A. 2003. Corporate governance and equity prices. Quarterly Journal of Economics, 118(1): 107-155.

Graffin, S. D., Boivie, S., \& Carpenter, M. A. 2013. Examining CEO succession and the role of heuristics in early-stage CEO evaluation. Strategic Management Journal, 34(4): 383403.

Gramm, C. L., \& Schnell, J. F. 2001. The use of flexible staffing arrangements in core production jobs. Industrial \& Labor Relations Review, 54(2): 245-258.

Gustman, A. L., Mitchell, O. S., \& Steinmeier, T. L. 1994. The Role of Pensions in the LaborMarket: A Survey of the Literature. Industrial \& Labor Relations Review, 47(3): 417438.

Guthrie, K., \& Sokolowsky, J. 2010. Large shareholders and the pressure to manage earnings. Journal of Corporate Finance, 16(3): 302-319.

Hadani, M., Goranova, M., \& Khan, R. 2011. Institutional investors, shareholder activism, and earnings management. Journal of Business Research, 64(12): 1352-1360.

Hallock, K. F. 2009. Job Loss and the Fraying of the Implicit Employment Contract. Journal of Economic Perspectives, 23(4): 69-93.

Hewitt Associates. 2003. Survey Findings. Current Retirement Plan Challenges: Employer Perspectives 2003. Hewitt Associates, Lincolnshire, IL.

Hoskisson, R. E., Hitt, M. A., Johnson, R. A., \& Grossman, W. 2002. Conflicting voices: The effects of institutional ownership heterogeneity and internal governance on corporate innovation strategies. Academy of Management Journal, 45(4): 697-716.

Ippolito, R. A. 1987. The Implicit Pension Contract: Developments and New Directions. Journal of Human Resources, 22(3): 441-467.

Ippolito, R. A., \& James, W. H. 1992. LBOs, reversions and implicit contracts. Journal of Finance, 47(1): 139-167.

Jackall, R. 1988. Moral Mazes: The World of Corporate Managers. New York: Oxford University Press.

Jensen, M. C., \& Meckling, W. H. 1976. Theory of Firm: Managerial Behavior, Agency Costs and Ownership Structure. Journal of Financial Economics, 3(4): 305-360.

Johnson, R. A., \& Greening, D. W. 1999. The effects of corporate governance and institutional ownership types on corporate social performance. Academy of Management Journal, 42(5): 564-576.

Jung, J. 2014. Shareholder Value and Workforce Downsizing, 1981-2006. Social Forces, Forthcoming: 1-34.

Jung, J., \& Dobbin, F. R. 2014. Finance and Institutional Investors. In K. K. Cetina, \& A. Preda (Eds.), The Oxford Handbook of the Sociology of Finance: 52-74. Oxford: Cambridge University Press.

Kacperczyk, A. 2009. With Greater Power Comes Greater Responsibility? Takeover Protection and Corporate Attention to Stakeholders. Strategic Management Journal, 30(3): 261285. 
Kiser, E. 1999. Comparing varieties of agency theory in economics, political science, and sociology: An illustration from state policy implementation. Sociological Theory, 17(2): 146-170.

Koh, P.-S. 2007. Institutional investor type, earnings management and benchmark beaters. Journal of Accounting and Public Policy, 26(3): 267-299.

Kotlikoff, L. J., \& Wise, D. A. 1985. Labor compensation and the structure of private pension plans: Evidence for contractual vs. spot labor markets In D. A. Wise (Ed.), Pensions, labor, and individual choice: 55-85. Chicago, IL: University of Chicago Press.

Kruse, D. L. 1995. Pension Substitution in the 1980s: Why the Shift toward Defined Contribution. Industrial Relations, 34(2): 218-241.

Landsman, W. 1986. An Empirical Investigation of Pension Fund Property Rights. Accounting Review, 61(4): 662-691.

Lazear, E. P. 1986. Retirement from the Labor Force. In O. Ashenfelter, \& R. Layard (Eds.), Handbook in Economics Series: 305-355. New York: Elsevier Science Publishers.

Longo, B. 2000. Spurious Coin: A History of Science, Management, and Technical Writing Albany, NY: State University of New York Press.

Manne, H. G. 1965. Mergers and the Market for Corporate-Control. Journal of Political Economy, 73(2): 110-120.

March, J. G. 1962. The Business Firm as a Political Coalition. Journal of Politics, 24(4): 662678.

Mitchell, R. K., Agle, B. R., \& Wood, D. J. 1997. Toward a theory of stakeholder identification and salience: Defining the principle of who and what really counts. Academy of Management Review, 22(4): 853-886.

O'Barr, W., \& Conley, J. M. 1992. Fortune and folly: The wealth and power of institutional investing. Homewood, IL: Business One Irwin.

Ocasio, W., \& Kim, H. 1999. The circulation of corporate control: Selection of functional backgrounds of new CEOs in large US manufacturing firms, 1981-1992. Administrative Science Quarterly, 44(3): 532-562.

Orr, D. V. 1998. Strategic bankruptcy and private pension default. Journal of Economic Issues, 32(3): 669-687.

Parrino, R., Sias, R. W., \& Starks, L. T. 2003. Voting with their feet: institutional ownership changes around forced CEO turnover. Journal of Financial Economics, 68(1): 3-46.

Peng, M. W., \& Sauerwald, S. 2013. Principal-Principal Conflicts. In M. Wright, D. Siegel, K. Keasey, \& I. Filatotchev (Eds.), The Oxford Handbook of Corporate Governance: 658672. New York: Oxford University Press.

Pfeffer, J., \& Salancik, G. R. 1978. The External Control of Organizations: A Resource Dependence Perspective. New York: Harper \& Row.

Picconi, M. 2006. The perils of pensions: Does pension accounting lead investors and analysts astray? Accounting Review, 81(4): 925-955.

Prahalad, C. K., \& Bettis, R. A. 1986. The Dominant Logic: A New Linkage between Diversity and Performance. Strategic Management Journal, 7(6): 485-501.

Rauh, J. D. 2009. Risk Shifting versus Risk Management: Investment Policy in Corporate Pension Plans. Review of Financial Studies, 22(7): 2687-2733.

Revell, J., \& Tkaczyk, C. 2002. Beware the pension monster, Fortune, Vol. 146: 99.

Selznick, P. 1948. Foundations of the Theory of Organization. American Sociological Review, 13(1): 25-35.

Shapiro, S. P. 2005. Agency theory. Annual Review of Sociology, 31: 263-284. 
Shin, J. Y., \& Seo, J. 2011. Less Pay and More Sensitivity? Institutional Investor Heterogeneity and CEO Pay. Journal of Management, 37(6): 1719-1746.

Shleifer, A., \& Summers, L. H. 1988. Breach of Trust in Hostile Takeovers, NBER Chapters in Corporate Takeovers: Causes and Consequences: 33-68: National Bureach of Economic Reserch Inc.

Simon, H. A. 1947. Administrative Behavior: a Study of Decision-Making Processes in Administrative Organization (1 ed.). New York: Macmillan.

Skinner, B. F. 1953. Science and Human Behavior. New York: Macmillan.

Skinner, D. J., \& Sloan, R. G. 2002. Earnings surprises, growth expectations, and stock returns or don't let an earning torpedo sink your portfolio. Review of Accounting Studies, 7: 289-312.

Solomon, D., \& Hawkins, L. J. 2005. Pension Inquiry Shines Spotlight on Assumptions [Electronic version], The Wall Street Journal: C1.

Sundaram, R. K., \& Yermack, D. L. 2007. Pay me later: Inside debt and its role in managerial compensation. Journal of Finance, 62(4): 1551-1588.

Tihanyi, L., Graffin, S., \& George, G. 2014. Rethinking Governance in Management Research. Academy of Management Journal, 57(6): 1535-1543.

Tihanyi, L., Johnson, R. A., Hoskisson, R. E., \& Hitt, M. A. 2003. Institutional ownership differences and international diversification: The effects of boards of directors and technological opportunity. Academy of Management Journal, 46(2): 195-211.

Towers Watson 2010. Towers Watson-Forbes Insights 2010 Pension Risk Survey. Towers Watson, New York.

U.S. Government Accountability Office (2009) Private pensions: Alternative approaches could address retirement risks faced by workers. Report, U.S. Government Accountability Office, Washington, DC

Useem, M. 1993. Executive Defense: Shareholder Power and Corporate Reorganization. Cambridge, MA: Harvard University Press.

Useem, M. 1996. Investor Capitalism: How Money Managers are Changing the Face of Corporate America. New York: Basic Books.

Velasco, J. 2006. The Fundamental Rights of the Shareholder. University of California, Davis Law Review, 40(407): 409-467.

Walsh, J. P., \& Seward, J. K. 1990. On the Efficiency of Internal and External Corporate-Control Mechanisms. Academy of Management Review, 15(3): 421-458.

Waring, M. B. 2012. Pension Finance: Putting the Rissks and Costs of Defined Benefit Plans Back under Your Control. Hoboken, NJ: John Wiley \& Sons, Inc.

Weber, M. 1978. Economy and Society: An Outline of Interpretive Sociology. Berkeley, CA: University of California Press.

Western, B., \& Rosenfeld, J. 2011. Unions, norms, and the rise in U.S. wage inequality. American Sociological Review, 76(4): 513-537.

Wooldridge, J. M. 2006. Introductory Econometric Analysis. Mason, OH: Thomson.

Zhang, X. M., Bartol, K. M., Smith, K. G., Pfarrer, M. D., \& Khanin, D. M. 2008. CEOs on the edge: Earnings manipulation and stock-based incentive misalignment. Academy of Management Journal, 51(2): 241-258. 